\title{
Church Models for the 21st Century
}

\author{
Stanko Jambrek \\ The Bible Institute, Zagreb \\ sjambrek@bizg.hr
}

UDK: 27-72:27-523

Original scientific paper https://doi.org/10.32862/k.13.1.2

\section{Abstract}

In order to have a fruitful understanding of the nature of the Church, the Bible uses a variety of pictures, which when taken together form Church models by which believers live and act by. We have reviewed Church models in three categories: the first category is taken by Church models which are formed today by our everyday life; the second one are Church models which have been created by man throughout history; and third, the Church models which have a foundation in the Word of God.

Church models formed by everyday life and man-made Church models can be used as negative examples of models to be changed and avoided, especially models of the Church as an institution and as a denomination. The Bible shows a particular reality and nature of the Church by using numerous different pictures from everyday life. These include pictures from the ownership system; the picture of the way the human body works; pictures from premarital, marital, and family life; pictures from architecture, agriculture, cattle breeding, fishery, and citizenship and patriotism. Each of the used pictures communicates one or more God's truths in a way that is experientially very close and familiar to the listeners and readers. These pictures reflect life and point towards life.

The 21st century Christianity needs to adopt and apply Biblical pictures of Church which, when taken together, form the Biblical Church model. As we establish this model, we need to focus on God and His purposes and plans for a specific time, place, and culture. Our communication with God needs to be completely open, and the Church needs to be prepared to follow God's 
plans and the guidance of the Holy Spirit. The Biblical Church model contains God's (immutable) and human (mutable) elements. God is immutable, which is why anything that is permanent and immutable in Church comes from God, and what can and needs to be changed is anything that came from people. The human elements need to be aligned with God's Word and the Holy Spirit's guidance, so that the Church would be able to obey God's will fruitfully.

Key words: Church, pictures of the Church, Church models, God's people, the Body of Christ, Christ's betrothed

\section{Introduction}

In its teaching about the Church, the New Testament uses pictures and models in order to help us better understand the overall reality of the Church. The picture is both a reflection and a description of reality. The picture of the Church is a reflection of reality from one standpoint. No single picture can fully reflect and express the entire reality, but only a reality as seen from one standpoint, from a certain perspective. Therefore, in order to bring us a fruitful understanding of the nature of Church, the Scriptures use a series of pictures which together create the models of the reality of Church. Using multiple pictures to describe the Church in the New Testament points us to the fact that we should not and must not focus on just one or two of them, but instead, as we study and apply it, we need to meditate on all of the New Testament pictures of the Church in order to understand the complete reality of the Church, the way the Holy Spirit intended to reveal it in the Scriptures.

Since the human mind is limited, the Bible uses pictures and models from reality and from everyday situations and experiences. The messages that are communicated by Biblical pictures for the Church, as they are applied in life, become the visible model of the Church. A model is a visible multidimensional picture which both represents and reveals various aspects of the mystery of Church. Biblical pictures for Church reveal different dimensions and standpoints for God's model of the Church. A comprehensive modern model of the Church needs to include all Biblical pictures and to exclude all man-made and culturally conditioned models and elements of models which are directly or indirectly opposed to the Word of God.

How do models of the Church come about? The process of establishing the Church begins when God starts to work in individuals. Then, those changed individuals respond to God's calling and task to evangelize others. They do this under the guidance of the Holy Spirit, by knowing God and His Word, through 
their own character, skills, and education in special theological, cultural, political, and social circumstances. The model of a new Church is influenced by all of these factors. Therefore, the models will differ from one another depending on the order and impact of the model element variables.

The adopted model of the church either allows or hinders the Holy Spirit from being active in the congregation of believers. ${ }^{1}$ As Jesus Christ goes on to build His Church in the power of the Holy Spirit, any model which hinders the Spirit from working needs to be changed on the basis of God's Word. Every church needs to be re-evaluated by God on occasion. We find an example of God re-evaluating individual Churches in Revelation, chapters 2 and 3. God had analyzed seven churches, and he informed each one of them about their spiritual condition through apostle John. For each of these seven churches, God emphasized what good things he found about it, he also emphasized the bad things he found about it, and he encouraged the Church to keep doing the good thing, he offered a solution for what is not good, and he informed the believers about what would happen to them if they persist in doing what is evil in God's eyes. In conclusion, he encouraged them not to give up the fight, because the winners will be rewarded. Four out of seven churches have not passed God's evaluation, and God called on them to come back to him and to start doing the works they were first doing again.

We will review Church models in three categories: the first category are Church models which are created by everyday life today; the second category are Church models that were created by people throughout history; and the third are the Church models which are based on God's Word. ${ }^{2}$

1 Thus, for example, the adopted model of the early Church allowed the Holy Spirit to work (cf. Acts 13:1-4). The Spirit was able to direct and guide the Church, because the leaders were Godfearing and obeyed God, and believers were trained in discerning the guidance of the Holy Spirit. We can find examples of the Spirit's guidance all over the New Testament, especially in Acts (cf. Acts 16:4-8). The work of the Holy Spirit is significantly limited, and often even ignored and hindered in Church models with strong human elements, such as when applying philosophy, rational way of thinking, attempting to be socially and culturally relevant, managerial way of leading, etc.

2 Church models have been altered during history under various influences. The historical Church models, or seven ecclesiological traditions, were summarized by Veli-Matti Kärkkäinen in his book, "Introduction to Ecclesiology: Ecumenical, Historical and Global Perspectives." These include: the Church as the icon of Trinity (Eastern Orthodox tradition), the Church as God' people (Roman Catholic tradition), the Church as both righteous and sinful (Lutheran tradition), the Church as a covenant (Reformed tradition), the Church as a community of believers (tradition of the free Churches), the Church in the power of the Spirit (Pentecostal / Charismatic traditions), the Church as one (Ecumenical tradition). 


\section{Church Models Which are Created by Everyday Life Today}

We will begin our discussion about Church models by reviewing contemporary models which were created and formed by the life and work of different congregations, all of which claimed to be the authentic Church. Those models have been theoretically and philosophically explained or scientifically based but are a copy and a reflection of true life in a congregation of believers. Believer congregations are usually called into well-explained and Biblical Church models, but they mostly fail or partially succeed to realize those models in life together. Therefore, despite the good desires which are founded in the Bible, under the pressure of various life influences, the communal life in a congregation of believers shapes a Church model which is significantly different than the New Testament Church models.

While Biblical pictures do point us to God's plan for Church models, the pictures and Church models created by everyday life indicate the true condition of the Church. While denominations teach about the ideal model of how the Church should work, in practice they are under the heavy influence of the contemporary cultural, social, and political trends and movements, as well as modern economy and technology. Out of a multitude of contemporary models, I would like to single out the following ones:

Religious Repair Shop. The Church as a religious repair shop is the most widespread Church model that was created by everyday life during history. This model works very similar to any other model of a contemporary car repair shop. Just like it is normal to take your car to the mechanic once a year, or when something breaks down, in the same way many believers go to Church once a year, otherwise they only come when they feel an urge or when they need an encouragement, comfort, peace, or some other service from the religious repair shop. ${ }^{3}$ The Church then serves as a repair shop for the spiritual needs of believers. Although we can find elements from this model in every believer congregation, the religious repair shop is most obvious in the Roman Catholic and Eastern Orthodox Churches.

Religious Corporation. The model of Church as a corporation was probably the most widespread model at the turn from the 20th to the 21st century, and it is

3 This practice is prescribed in the Roman Catholic Church in Croatia in the 3rd Church command, which states, "Go to confession at least once a year and receive the Holy Communion during Easter!" The explanation for this command reads, "It is the obligation of any Catholic who has received the first Holy Communion to confess his sins at least once a year and to receive the Holy Communion during Easter time. If one is unable to come to Church, they must call for a priest. Failing to go to confession once a year and to receive the Holy Communion is a severe sin." (Five Church Commands - with the work sheet. Religious education portal. http://vjeronaucniportal.com/pet-Crkvenih-zapovijedi-s-radnim-listom/, visited on June 28th 2018) 
becoming more and more obvious in modern Protestant and Evangelical Churches. It was shaped after business world structures. ${ }^{4}$ The Church has become just like any other secular enterprise or organization which gathers people for the purpose of making money and promoting their product. A deeply secularized and pragmatic Church is attempting to apply the business model, which at its core is about the profit, budget, employees, and marketing the product (salvation and a relationship with God). The Church is like a business enterprise which is trying to sell its product on the market, and in those efforts God's will, truth, and his plans are only welcome if they fit into the plans of church as a corporation. The Church is gathering with the purpose of responding to social needs and not doing God's will, and it is managed as a successful corporation which works on the needs of the social community. The church is lead by managers and leaders thus the Church structure is very similar to that of any corporation.

Religious Theater. Some congregations have skilfully managed to turn Church gatherings into a religious theater. Just like the only purpose of the theater is entertainment, some Churches try to do anything to keep their believers entertained. Church gatherings have been excellently planned, the script is predetermined, and the art program is practiced to perfection. The hosts are excellent at leading worship services, the pastors deliver "anointed" sermons, the priests give powerful reviews regarding social and political topics, the musicians are doing a great job at playing music, and fundraisers are very meticulous about doing their part. The believers can approve or disapprove, they can boo or clap, at the end they spend some time in the lobby, they exchange the learned pleasantries about how good it was, and they go home with no change in their lives.

Religious Classroom. The model of Church as a religious classroom has seemingly become the standard church model in Protestant tradition and in some Evangelical churches. The seats are turned towards the central, elevated pulpit, from which the pastor or preacher read and preach from the Bible to the mostly passive congregation.

Religious NGO. Some Churches operate as NGO's (non-government organizations). However, NGO's are particular. They usually start due to one person's ambitions, who then gathers a few people around themselves and their goals as members of the NGO. Members are important to NGO's. They are needed for achieving the NGO's goals and programs, for attending meetings regularly, to

4 The corporation Church model was popularized by Bill Hybels in Willow Creek Community Church (Chicago, Illinois), and Rick Warren in Saddleback Church (Lake Forest, California), among others. In Croatia, it became popular through Rick Warren's books and at The Global Leadership Summit conferences, where successful business people, mostly non-Christians, have taught Christian leaders on how to lead the Church (https://global.willowcreek.com/pages/home/home.html\#/?CountryName=Croatia\&RegionName=Europe). 
pay their membership fees on time, and to live an adequate life in line with the NGO's standards. And that is it. The religious NGO model can be found in in some free Churches, especially the charismatic ones. Under the influence of the church-planting movement, the self-proclaimed leaders, who are supported by their friends and like-minded people, begin to gather believers, and they go on to declare their group to be a Church, and then they start to accomplish the goals and programs which the leaders have envisioned.

Tour Bus. In the older Reformation-heritage Churches in Croatia, there is a special appreciation of the model of Church as a tour bus. A tour bus gathers a merry company of people who want to reach the planned destination and have a good time and a lot of fun. They are on the road. They know where they want to arrive and what they want to see. The bus driver needs to take them on the correct road and bring them to their destination. That is what he is paid for. During the trip, he must entertain the passengers, and they can either enjoy the view or stare at the back each other's heads. This model is really noticeable in the Church. The Church is on its way to heaven, and the pastor (or the preacher or the elder, depends on how the congregation calls its leader) is the driver. The pastor's task as the driver is to "drive" the congregation into heaven. $\mathrm{He}$ knows the way, and the members can remain carefree. They enjoy their life in the closed bus (i.e., local Church) which is traveling through the social expanses. When they stumble upon people in trouble during their voyage, they offer them a pitiful wave as per usual, they mutter a brief prayer, and they keep "driving" towards "heaven." The pastor, as the driver of this tour bus, only stops the bus when some of the passengers need to relieve themselves. In the tour bus model of the Church, neither the pastor nor believers are interested in what's going on around them, and they sure will not stop and help people in their trouble using their programs. This community of believers is on its way on a meticulous manmade road to "Heaven."

Christian on Sunday, Atheist on Monday. It is a Church model in which faith is separated from the real, everyday life. There is a strong emphasis on religious professing and attending "Church" on Sundays, without any integration of faith into everyday life and the work week.

The iGod App Church Model. For some people, the Gospel is the iGod app, which allows the person to have a wi-fi connection with Heaven (where the Internet is the only mediator between man and God). In this model, the Church has been reduced to a weekly meeting with Jesus' Facebook friends (Bird 2013, 703 ) and to spiritual consumerism, i.e., to selecting and adopting those contents (sermons, lectures, worship) in the global spiritual supermarket (Internet, YouTube) which the individual likes best. The emphasis is on the "me and Jesus" relationship, not the "we and Jesus" relationship. In this Church model, teaching 
that tickles people's ears (cf. 2 Tim. 4:3-4) is at the center, because believers do not participate in communal worship and Word, which was prepared through inspiration by the pastor of the local congregation for the needs of that particular church; instead, each believer finds their favorite type of sermon on the Internet according to their own desire, which usually just tickles their ears, i.e., confirms what they want to hear. By personally selecting sermons and worship, the believer spiritually closes his ears to those sermons which he should be hearing but he dislikes them, thus hindering God in his work. This Church model ignores the communal identity and the commission of God's people, united in Jesus Christ.

In thinking about the life and work of the Church, we need to consider all the mentioned and other Church models which are created by life every day. Each of these models contains elements we can learn from, but none of them fully reflects the true essence of the Church as described in the New Testament. Analyzing Church models which are created by life every day helps us recognize and consider what the Church should not be like.

\section{Man-Made Church Models Throughout History}

In the life of the Church throughout history there emerged numerous man-made Church models, mostly under the strong influence of philosophy, politics, cultural, and social trends. Some of these models only partly include the Word of God, along with the worldly elements, and some almost fully leave out the Word. Among the numerous Church models which people have invented throughout history and which are barely influenced by the Word of God, two models stand out: Church as an institution, and Church as a denomination. The Church as an institution is the basic model for the Roman Catholic, Orthodox, and Anglican Churches, and we can also find a number of this model's elements in Protestant Churches. The model of the Church as a denomination is most common in Protestant and Evangelical Christianity.

A review and analysis of the most significant and most influential Roman Catholic Church models from the Roman Catholic perspective was published by the cardinal, Avery Dulles (1918 - 2008) in his book, Models of the Church. ${ }^{5}$ The

5 The first edition of the book was published in 1974 and it contains the analysis of five most significant models of the Roman Catholic Church. The model analyses in the book mostly refer to his works that were written directly before, during, and after the Second Vatican Council (1962 - 1965). In the expanded edition, (1987) Dulles added the chapter, "The Church: Community of Disciples", in which he analyzed the model of the Church as a community of disciples. 
book presents five primary models of the Roman Catholic Church: institution, mystic fellowship, sacrament, messenger (proclaimer), servant. The author analyzes the strengths and weaknesses of each model and in conclusion, he integrates the contributions of each model. Since the institution model of the Church includes all of Dulles' models, we will devote most of the time to it, and we will just mention the others.

\section{The Church as an Institution}

The model of the Church as an institution has been the central model of the Roman Catholic Church for centuries, and it is still prevalent in Croatia today. Church as an institution operates as a "perfect society" in the sense that it does not answer to anybody else and it needs nothing in order to be institutionally complete (Dulles 1987, 34). The modern Church model as an institution relies on the counter-Reformation documents from the Council of Trent and the teaching of Robert Bellarmin (Dulles 1987, 16.34), which describes the Church using political analogies adopted from the general society. The template according to which the Church is organized as an institution with a hierarchical administration was the Roman Empire, which took pride in efficiency and responsibility. By defending the institutional model, Cardinal Avery Dulles $(1987,35)$ emphasizes that Christianity possessed some institutional elements from its very beginnings. It had recognized ministries and ministers, accepted confessional creeds, and prescribed forms of public worship. These institutional elements were often in the center of Church life and they created institutionalism, a system where the institutional element was considered to be primary. The fruits of this system include clericalism, juridic practices, and triumphalism (Dulles 1987, 39). Clericalism has led to the division of the Church into the clergy and the laymen, and only the clergy were considered to be the real Church. The juridic practice applies the Canonic Law, which defines relationships in accordance with the legal position of the believers within the Church, prescribes the ways these relationships are implemented, describes the hierarchical order in the Church, prescribes its activities, and assesses and prescribes the behavior of believers. Triumphalism dramatizes the Church as an army that is lined up for a fight against Satan and the forces of evil.

According to Dulles $(1987,35)$, institutionalism is a deviation in the true nature of the Church; a deviation which has had a strong impact on the Church in certain periods of its history; a deviation which in any period remains a true threat to the institutional Church. Dulles believes that a Catholic can both oppose institutionalism and remain devoted to the Church as institution at the same time. 
Model of the Church as an institution primarily emphasizes the institutional elements, such as an office, doctrine, law, and ritual forms. People, their relationship with God, the working of the Holy Spirit in people and through them, and the Bible as the Word of God and the standard of truth have often been subjugated to institutional elements. According to Dulles (1987, 36), Catholic theology in patristic times and in the Middle Ages was relatively free from institutionalism. Powerful institutionalism, Dulles considers, is only developed during the late Middle Ages and during the counter-Reformation, and it culminated in the second half of the nineteenth century, in the first draft of the Dogmatic Constitution on the Church that was prepared for the First Vatican Council. On the other hand, Protestant author emphasize the fact that institutionalism was strongly present and prevalent in the Church ever since the Church became secularized during and after Emperor Constantine in the 4th century and that it is strongly noticeable in the Roman Catholic Church of the 21st century as well.

In the institutional ecclesiology, the power and the function of the Church are principally threefold: teaching, consecration, and rule (Dulles 1987, 37). The function of teaching is similar to a school where lecturers, as holy teachers, give the teaching of Christ. Since it is implied that the bishops possess the "charisma of truth," it is believed that the believers have a conscientious duty to believe the bishops' teachings (Dulles 1987, 38). The Church is, Dulles goes on, a unique kind of school: one where the teachers have the power of imposing the approved doctrine using juridic and spiritual sanctions. The Pope and the bishops, assisted by priests and deacons, perform the ministry of consecration through giving out sacraments, like engineers who open and close the valves of grace. The function of consecration is completely juridic and institutionalized. The function of rule in the matters of faith and morality is in the hands of the hierarchy.

The hierarchical concept of authority is the basic characteristic of the institutional model of the Church. The fullness of Church's power has been concentrated in the hands of a small hierarchical group of people, which renews itself by co-optation.

In the institution model of the Church, the key role is taken by hierarchy and sacraments (Dulles 1987, 41). The Roman Catholic Church teaches that the hierarchy (the Pope, bishops, and priests) and the seven sacraments were established by Christ Himself. The users of the Church are its own members. The Church is the school which teaches them about the truth which they need to know for their eternal salvation. It is a dwelling place where they drink and eat from the lifegiving streams of grace, which flow most abundantly through the sacraments. It is in the hospital where the sick are healed; the shelter where they are protected from the attacks of the enemy of their souls. Through its authority, hierarchy keeps the believers from wandering the desert and leads them to green pastures 
(Dulles 1987, 41). Dulles compares the institutional Church with a loving mother who is breastfeeding her children, and all they have to do is be obedient and submissive, and to rely on the Church's ministries. In the institutional model of the Church, it attempts to remain fully the only institution which lives for itself, and only serves others by magnifying itself (Dulles 1987, 42).

Finally, Dulles emphasizes three strengths and five weaknesses of the institution model of the Church. The first strength is that this model finds strong confirmation in Church documents from the last few centuries. Since the Church magisterium persists in claiming that the doctrinal, sacramental, and leading structures are based on divine revelation, it is difficult for believers to take a different position. Second, by emphasizing the element of continuity with the Christian sources, the model provides an important link between the uncertain present day and the attested past. Thirdly, during the last few centuries, this model has served as a strong support for the common Roman Catholic identity.

The biggest weakness of the institutional model of the Church is the fact that it has no foundation in the Scriptures nor in the early Church tradition. There are very few New Testament verses it can refer to, and even those need to be interpreted in a specially prescribed way. The Holy Scriptures, Dulles emphasizes $(1987,43)$, do not portray the Church as a single tightly knit society. Second, the institutional model of the Church leads to some inevitable consequences in Christian life, both personal and communal. Clericalism places a strong emphasis on the division between the active clergy, who are the Church, and the believers (lay people), who are passive members of the Church. The juridic practice aims to emphasize the role of the human authority, thus diminishing the authority of the Scriptures. Since they are preoccupied with maintaining a correct relationship with the Pope and the bishops, believers leave out and/or neglect God the Father, Jesus Christ, and the Holy Spirit. Here, Dulles is being very critical of his own Roman Catholic Church. He points out the example of Jesus, who was very critical towards institutionalized religion of His day, and He founded His own authority not on institutional ordinance or ministry, but on the Holy Spirit through which He spoke. Third, the institutional model is setting obstacles to a creative and fruitful theology. It identifies religion with defending the current formal position and it diminishes the possibility of critical thinking. Fourth, the institutional model uses an abundance of worldly and pagan practices, which not only are not rooted in the Scriptures, but are even opposed to its teaching. Dulles $(1987,44)$ lists some of them: the papal-episcopal form of leadership, the seven sacraments, the dogmas regarding Mary's immaculate conception and ascension. And the most significant fault in this model is the fact that gifts and graces of the Holy Spirit need to wait for confirmation and approval from the hierarchy. The final weakness of this model, 
as stated by Dulles, are monopolistic tendencies which are unacceptable in the age of dialogue, ecumenism, and interest in world's religions.

Dulles $(1987,205)$ thinks that some of the problems with the institutional model of the Church can be overcome if the institution is understood not only in the sociological sense, but also in the sense of that which God has "established" in Christ. It is important for the Church members to be able to find a continuing presence of Christ in the Church as a visible community. In other words, there are thoughts about the Church as an institution where the institutional elements are not opposed to people and their spirituality as a fruit of Christ's presence.

The Church as a Mystical Communion. Using the model of the Church as a mystical communion, Dulles $(1987,50)$ connects the Biblical pictures of God's people and the Body of Christ. In this perspective, the Church consists of faithful men and women who are connected via their co-operation in God's Spirit through the living Christ. The nature of this fellowship is not institutional, but rather pneumatological, communal, and personal. "The purpose of the Church in this second ecclesiological type is spiritual, or supernatural. The Church has the purpose of leading people into fellowship with the divine" (Dulles 1987, 58). As a mystic community, the Church is not primarily an institution or an organized community, Dulles emphasizes $(1987,55)$ and goes on to explain that, instead, the Church is a fellowship of people which is outwardly expressed through the bonds of belief, worship, and Church fellowship.

The power of the Church as a mystical communion is in its emphasis on the dynamic congregation which the Holy Spirit has created in the relationship with God and the relationship with brothers and sisters. A potential downside of this model is the danger of it degenerating into a mere Christian fellowship without objective theological content.

The Church as a Sacrament. The sacramental model is a view which focuses on the Church as Christ's constant presence in the world. With this model, the author is aiming to bring institutional and the mystic fellowship models closer together, thus maintaining the institutional structure which he tries to instill with dynamic spiritual life. The sacrament is understood as a way of making the sacred reality present and active. Just as Christ can be considered God's sacrament, so the Church can be considered Christ's sacrament. The Church as a sacrament is both a sign and a mediator of God's grace to the world. As an embodiment of grace which it symbolizes, the Church exists as God's presence before the nations.

The Church as a Herald. The model of the Church as a herald emphasizes the authority and primacy of the Bible. The Church is made up from those who have heard the Word and who have turned to God on the basis of the Word. The Church has been tasked with preaching the Word of God to the ends of the earth. The emphasis is placed on obeying and preaching the Word of God. 
The Church as a Servant. The model of the Church as a servant emphasizes the need for the Church to be involved in social transformation. The Church should be considered a part of the general human family, sharing the same concerns as all other people (cf. Dulles 1987, 89-102). Church members as part of the larger human family need to be in service to the world, which is essentially good. This model emphasizes that Lord Jesus was "a man for the people," which is why the Church also needs to be "a community for the people." This Church model has been developed according to the thoughts of liberal theologians and is very noticeable in the Roman Catholic liberation theology in Latin America and in liberal Protestant theology. Dulles $(1987,98)$ concludes that the model of the Church as a servant is trying to provide the Church with new relevance, new vitality, new modernity, and a new meaning of mission. However, he solemnly remarks that the model of the Church as a servant lacks any direct Biblical elements (1987, 98-100). The Church is not and must not be a servant of the world, as is suggested by this liberal model; but like its Head, who is Jesus Christ, it must be God's servant in the world.

The Church as a Community of Disciples. In the revised edition to the book, Models of the Church, in the Addendum, Dulles discusses the model of the Church as a community of disciples $(1987,204-226)$. He believes that the community of disciples' model is not just another model to be added to all the others; instead, it is an inclusive model which is able to integrate all the best elements from the other five models. The model focuses on discipleship in the context of the Roman Catholic Church as an institution, mystic fellowship, sacramental practice, herald of God's Word, and the servant to the world. The model is intended to shed light on the purposes of institutional structures and sacramental aspects of the Church, with the purpose of missionary exhortations for evangelism and social transformation.

\section{The Church as a Denomination}

Although the picture of the Church as a denomination has been present since the days of Reformation, using the word, denomination, for describing a group of Christians first appeared around 1740, in the early years of Evangelical renewal lead by John Wesley and George Whitefield. The term, denomination, stands as the opposite to the term "sect," and denominationalism is the opposite of sectarianism. A sect appropriates the authority of Jesus Christ for itself. It believes to be the only true body of Christ, and that all truth belongs only to it and nobody else. Sects are exclusive. Denomination is an inclusive term. It is implied that Christian groups are called, or denominated, by a special name in a larger group - the 
Church - to which all denominations belong. ${ }^{6}$

The denominational theory of the Church emphasizes that the true Church cannot be identified with any single Church structure. No single denomination appropriates the right of representing the entire Church of Christ. Through different worship practices and organization, each denomination contributes its own form of Church life.

The denominational Church theory was developed by congregationalists, who represented the minority in the Westminster Assembly (Westminster Assembly: 1642-1649) in England. The majority in the Assembly represented Presbiterian principles, which were expanded on in the Westminster Confession of Faith and in the Westminster extended and abridged catechisms. The proponents of the independent Church, who stood for congregational principles, believed that the Church expresses unity even when the Christians do not fully agree. They have expressed their views in several fundamental truths: first, considering the fact that humans are incapable of always fully grasping the truth, differences in opinion regarding the outward forms of Church are inevitable. Second, even though these differences do not include the fundamentals of the faith, they are not insignificant. Each Christian is under obligation to practice what he believes the Bible to be teaching. Third, due to the fact that no single Church possesses the ultimate and complete understanding of the divine truth, the true Church of Christ can never be fully represented in one single Church structure. Fourth, Churches can be divided in many ways, and yet still remain united in Christ. The denominational Church theory sees Christian unity in the inner religious experience and allows for differences in the outward expressions of personal faith (Shelley 1995, 306-308).

Gelder (2001, 16-17) divides the historical development of denominations into five stages. The first stage encompasses the ethnic-voluntary denominations $(1600$ - 1800). These include denominations which were active from the beginning of the 17th century to the end of the 18th century as coalitions of European migrant churches. The second stage includes the targeted missionary denominations $(1800-1850)$. These denominations were formed during the first half of the nineteenth century as national organizational structures which were responsible for planting new churches in mission field. In the third stage of development, we see the emergence of the denomination as a Church (1850 - 1900). During the second half of the 19th century, denominations were starting to bu-

6 According to the World Christian Encyclopedia (1982), there were around a thousand and nine hundred church denominations registered at the beginning of the 20th century, while it is estimated that at the end of the century there were twenty two thousand (Omanson). When the revised edition of the World Christian Encyclopedia was published in 2001, there were 33 830 registered denominations in the world. 
ild institutional systems necessary for serving the needs of their members. The fourth stage of development includes corporate denominations (1900 - 1965) which have established different bureaucratic bodies for organizing the ministries of member churches during the first half of the 19th century. And eventually, phase five brings the development of regular denominations (1965 - today): the types of denominations which begin to increasingly use secular rules and policies in order to ensure compatibility with member Churches. Secular culture has changed the institutions of certain denominations, which used to transform the culture with the Word of God. Denominations develop bureaucratic structure which operate just like the bureaucratic structures of a democratic society. So now, denominations are led by presidents, secretaries, managers, and leaders, and local Churches are led by hosts, leaders, and managers with the support of boards. In denominations, decisions are made through the Church's political voting, and leaders are nor elected using Biblical standards, but using worldly standards in which the leadership and managerial qualities supersede the spiritual ones. Democracy ${ }^{7}$ was introduced into the Church, to the point that some authors have gone on to write about the democratic captivity of the Church.

The democratic captivity of the Church (see Small 2012) is reflected in the practice and conviction that the main responsibility of a meeting, assembly, or council of a denomination is accepting the report about the operations of local churches, various boards, committees, and organizations; and voting for rule books and procedural suggestions prepared by individual members, groups, and the denomination's bureaucracy. In this way, the denominational structures take the place of the Holy Spirit. Some of these have the purpose of connecting structures in denominations. The declarative purpose of these Church structures is to bring the denomination congregation members to common order and communal life. The other missionary structures in denominations exist as agencies for implementing different aspects of denomination's ministry (Gelder 2001, 18).

In the denominational structure of the Church, the fundamental "struggle" is for the authority of structures. Who will have the authority and over what? The struggle is for influence, and through influence, for power. More and more, denominations have been adopting bureaucratic business models and Church marketing after the example of the consumer society. Decision-making procedures are adopted, which are not based on Biblical principles, but try to mimic American style liberal democracy.

7 The democratic way of doing things in the Baptist churches in Croatia was analyzed by Danijel Časni in his paper, "The Church In A Democratic Society, And Democracy In ReformationHeritage Churches With The Emphasis On The Baptist Church in Croatia" published in Kairos: Evangelical Theological Journal 10/1, 2016, https://hrcak.srce.hr/160011 
Every year, traditional denominations are seeing a decline in the number of believers in Churches, as well as in the number of Churches. At the same time, new spiritual movements are emerging which are planting new Churches, which are then structured like denominations. These denominations spend some time growing and developing, and then they peak, after which they begin to decline and vegetate for decades, and even centuries. A significant negative role in this process is played by the democratic structure of denominations.

Summary. Man-made Church models stem from the fundamental misunderstanding of the nature of the Church and can lead into various problems. Defining the Church as an institution, denomination, or any other social construct twist the perspective and bring us further away from understanding the Church as a unique community of God's people and the Body of Christ. Instead of a community of believers where the Holy Spirit works in and through them, the Church has a tendency of maintaining and empowering man-made structures and ministries, such as worship, education, serving, and evangelism. Defining the Church organizationally in terms of its structures can distance our perspective from the spiritual reality of the Church, primarily as a spiritual, and then a social community (Gelder 2001, 22). Man-made Church models (institution, denomination) focus on human behaviors that need to be structured and guided. Such approaches reduce the Church to a sequence of ministries which are led through skills of managing for the purpose of maintaining efficiency, or an organization which is intended to achieve certain goals. Such functional and organizational approaches can enable leaders to stop trusting in God and guidance of the Holy Spirit, but in their own managerial skills or in using organizational techniques (Gelder 2001, 22).

\section{A Church Model That is Rooted in the Word of God}

The Bible portrays a specific reality and nature of the Church by using various pictures from everyday life. When communicating with man, God uses pictures which are very close to man, they are easy to understand and have been tested in experience. Those pictures are a reflection of life, and they point to life. Each one of the pictures communicates one or more God's truths in a way that is very close and familiar to the readers and listeners. In this section, we will explore some of the pictures for the Church found in the Bible.

\section{Pictures From the Ownership System}

The most important and fundamental picture of the Church comes from the ownership system. This system was and still is known to any person from their 
childhood until their old age. It was well known, although not very well liked by many, to believers of the today, and it is also known to the believers of today. The owner owns his property. He is free to dispose of his property any way he pleases.

To the crucial and fundamental question of, "Does the Church have an owner?" the Scriptures give a clear and emphatic answer: the Church does have an owner. The Church is God's Church (1 Cor. 1:2), God's field (1 Cor. 3,6-9), God's building (1 Cor. 3:9), God's temple (1 Cor. 3:16-17), God's people (2 Cor. 6:16; $1 \mathrm{Pt}$ 2:9-10), God's house (1 Pt. 4:17; Heb .3:3-6, and 1 Tim. 3:15), Christ's Church (Mt. 16:18; Col. 1:15-20), Christ's betrothed (2 Cor. 11:2). These pictures give us an insight into the ownership of the Church and into where the authority for ruling the Church, making plans, and executing decisions comes from. We will therefore analyse some of these pictures from the area of ownership, which are extremely important and necessary elements of the Biblical model of the Church.

God's People. In the Old Testament, we find a gradual development of the reality of Church. Genesis gives us an account of creating the first people, their sin, and a number of people chosen by God, and their relationship with God (Gen. 1:1 - 11:32). Only in God's relationship with Abraham do we find any information about a community of worshipers. God has chosen Abraham and he created a nation from Abraham's family - Israel, whom he had chosen for his purposes and ministry. God is explaining this as he reveals himself to Moses by the burning bush: "I have surely seen the affliction of My people who are in Egypt ...for I am aware of their sufferings. So I have come down to deliver them from the power of the Egyptians, and to bring them up from that land to a good and spacious land.... Therefore, come now, and I will send you to Pharaoh, so that you may bring My people, the sons of Israel, out of Egypt" (Ex. 3:7-8,10). God went on to confirm these words, "Say, therefore, to the sons of Israel, 'I am the Lord, and I will bring you out from under the burdens of the Egyptians, and I will deliver you from their bondage. I will also redeem you with an outstretched arm and with great judgments. Then I will take you for My people, and I will be your God; and you shall know that I am the Lord your God, who brought you out from under the burdens of the Egyptians" (Ex. 6:6-7).

In his sovereignty, God chose Abraham, and promised and gave him an offspring, and through his offspring He delivered the Israelites and chose them to be his people. This was later confirmed to the Israelites by Moses:

"For you are a holy people to the Lord your God; the Lord your God has chosen you to be a people for His own possession out of all the peoples who are on the face of the earth. The Lord did not set His love on you nor choose you because you were more in number than any of the peoples, for you were the fewest of all peoples, but because the Lord loved you and kept the oath which He swore to your forefathers" (Deut. 7:6-8). 
From of all the numerous nations, God has elected and separated Israel as his people for at least two reasons: because he loved them, and because he was making good on his promises (Deut. 9:5). Even though God has chosen the Israelites as his people out of his love for them, his actions on their behalf is conditioned. After the Israelites got out of Egypt, God said to Moses:

"Thus you shall say to the house of Jacob and tell the sons of Israel: 'You yourselves have seen what I did to the Egyptians, and how I bore you on eagles' wings, and brought you to Myself. Now then, if you will indeed obey My voice and keep My covenant, then you shall be My own possession among all the peoples, for all the earth is Mine; and you shall be to Me a kingdom of priests and a holy nation.' These are the words that you shall speak to the sons of Israel."

God's people were supposed to obey God and keep their covenant with him. Israel became God's people, not because they decided to call themselves the people of God, or because they were in any way distinguished among other nations, but solely through God's choice and his love for them. God's choice and love for the Israelites were conditioned. The Israelites were supposed to obey God faithfully and to keep his covenant, the basis of which was written in the Law. This Covenant was temporary, until the coming of Messiah.

The Old Testament goes on to tell us about Israel's continued failings in keeping their covenant with God. On one hand, Israel remained the chosen people of God, and on the other hand, Israel was constantly disobedient before God which is why God sent them into captivity and they need salvation and full purification. Only the saved can become the true people of God.

Israel's disobedience to God's commandments, as well as their incapability of keeping God's covenant, has caused God's righteous judgement on the people. The few saved believers were called "the Remnant" by God. "The Remnant" is faithful to God, and it will hold the future of Israel (cf. Ezr. 9:8-15; Is. 10:20-22; 28:5; 37:31-32; Am. 5:15; Mic. 2:12; 5:7-8; Zeph. 3:12-13; Zech. 9:11-12). The apostle Paul adopts this idea of a remnant and applies it to describe Jewish Christians as a remnant from the Jewish people, who have accepted Jesus as Messiah along with a multitude of pagans (cf. Rom. 9:27; 11:1-6).

The picture of the Church as the people of God has been significantly altered in the New Testament. ${ }^{8}$ The Church is a community of elected people whom God has called "out of darkness into His marvelous light" (1 Pt. 2:9). It is a community of people whom God has "saved... and called... with a holy calling, not according to our works, but according to His own purpose and grace" (2 Tim. 1:9). The

8 People of God in Old Testament were centered on three elements: the Temple, the priesthood, and the sacrifice. Jesus Christ ended all three, fulfiling them in Himself. 
picture of the Church as God's people is rooted in the Old Testament, in passages where Israel was called from Egypt to meet with God and to worship him on Mount Sinai, and then go on to live as a separate and sacred community among all the other nations.

The Church is not just a group of isolated individuals; it is a community of people whom God has called to live and serve together according to God's will and in the power of the Holy Spirit. It is a particular community of believers whose owner is God, and which lives among non-believers according to God's commands and standards. Apostle Paul admonishes the Corinthian Church in this truth, "Or what agreement has the temple of God with idols? For we are the temple of the living God; just as God said, 'I will dwell in them and walk among them; and I will be their God, and they shall be My people' (2 Cor. 6:16).

The New Testament picture of the Church as God's people contains several truths which are crucial for adopting the Church model for the 21st century:

The Church is the People of God. The emphasis of this claim is on ownership. God is not a servant to believers nor the Church, but is the owner of every believer, and consequently the entire community which gathers and works in His name. The apostle Peter emphasizes this reality: "But you are a chosen race, a royal priesthood, a holy nation, a people for God's own possession, so that you may proclaim the excellencies of Him who has called you out of darkness into His marvelous light; for you once were not a people, but now you are the people of God; you had not received mercy, but now you have received mercy" (1 Pt. 2:910). The Church as God's people consists of the remnant from faithful Jews and pagans who have believed in Jesus Christ. The Church is a mixed community of people who are gathered in the name of Jesus Christ. In the New Testament, God's people are a community of people who are no longer gathered around their race or ethnicity as in the Old Testament, but around God's calling in Jesus Christ.

The Church is the New People of God-Redeemed, Cleansed, Transformed, and Filled with the Holy Spirit. The apostle Paul writes about the redemption of Jesus Christ: "... who gave Himself for us to redeem us from every lawless deed, and to purify for Himself a people for His own possession, zealous for good deeds." (Titus 2:14). Through his work on the cross, Jesus Christ has redeemed all those who believe him from every kind of iniquity, including spiritual ties with evil, and from the power of Satan and evil forces. Redemption is a response to the need which arose through man's slavery to sin. The death of Jesus Christ was the ransom that was paid so that mankind can be delivered from sin and its punishment. The apostle Paul emphasizes, "For there is one God, and one mediator also between God and men, the man Christ Jesus, who gave Himself as a ransom for all" (1 Tim. 2:5-6). Jesus Christ as Redeemer breaks the power of sin and creates a new and obedient heart: he delivers us from sin, guilt, death, the Devil, and 
from the curse of the Law and God's wrath (Titus 2:14; Gal. 1:4; 3:13; 4:5; 5:1). Without this deliverance from curse, man would not be able to receive salvation. However, aside from being delivered from the curse of the Law, man is also delivered from slavery to the Law and from keeping the Law as a prerequisite for being accepted by God.

Redemption includes purification. God promised His people in the Old Testament, "Then I will sprinkle clean water on you, and you will be clean; I will cleanse you from all your filthiness and from all your idols" (Ez. 36:25). This promise was fulfilled in Jesus Christ (cf. Heb. 10:19, 22; Acts 10:34-38; 15:9; Eph. 5:25-26).

The new people of God are those people whose lives have been changed by God in accordance with His Old Testament promises. The prophet Jeremiah foreshadowed a New Covenant, in which God would write his Law in the hearts of his people (Jer. 31:31-33), and the Book of Hebrews confirms that Jeremiah's prophecy was fulfilled in Jesus Christ (Heb. 8:1-13; cf. Rom. 2:29; 8:3-4; Phil. 3:3). And not only did God promise to write His Law in the hearts of his people, but he also promised to give them one heart and one way, and that he will instill his fear in their hearts so they would never rebel against him again (cf. Jer. 32:38-40).

The prophet Ezekiel emphasizes God's promise, "And I will give them one heart, and put a new spirit within them. And I will take the heart of stone out of their flesh and give them a heart of flesh, that they may walk in My statutes and keep My ordinances and do them. Then they will be My people, and I shall be their God" (Ez. 11:19-20). God will replace their hearts of stone with a heart of flesh, so they could know and obey his Word and his will. This change took place and is taking place through the Holy Spirit, as the Scripture says about the Corinthian Church, "you are a letter of Christ, cared for by us, written not with ink but with the Spirit of the living God, not on tablets of stone but on tablets of human hearts" (2 Cor. 3:3).

God's promises that were given to his people regarding the new heart and spirit which he will breathe into them (cf. Ez. 36:26-27; 37:14) have been fulfilled in the New Testament. Jesus has promised his disciples that they will receive power when the Holy Spirit descends on them, and they will be his witnesses (Acts 1:8). This happened after the Holy Spirit came down (Acts 2:1-4). God sent the Spirit of his Son into the hearts of believers (Gal. 4:6), and he sealed them and put a deposit into their hearts: the Spirit (2 Cor. 1:22). God's love was poured into the hearts of believers (Rom. 5:5).

The New Testament picture of the Church as God's people implies a community of believers who are owned by God, who need to be separated from the world, whom God will abide in, who will happily bear witness to the fact that God is their personal God, and who will live and serve together according to God's will and through the power of the Holy Spirit. 
God's Church. The First Book of Corinthians was written "To the church of God which is at Corinth, to those who have been sanctified in Christ Jesus, saints by calling, with all who in every place call on the name of our Lord Jesus Christ, their Lord and ours" (1 Cor. 1:2). Aside from Paul strongly emphasizing God's ownership of the Church, he also lists the fundamental characteristics of those who are owned by God. It is all of those who have been sanctified in Christ Jesus, whom God has elected, called, and proclaimed to be holy, as well as all those who call upon the name of Jesus Christ everywhere.

The Chosen. God has produced a people from Abraham - Israel - whom he chose and separated from all other nations for his purposes and service. He revealed this to the Israelites, "For you are a holy people to the Lord your God; the Lord your God has chosen you to be a people for his own possession out of all the peoples who are on the face of the earth" (Deut. 7:6). God explained why he chose Israel among all other nations, "The Lord did not set His love on you nor choose you because you were more in number than any of the peoples, for you were the fewest of all peoples, but because the Lord loved you and kept the oath which $\mathrm{He}$ swore to your forefathers" (Deut. 7:7-8). Through this choice, God expressed his absolute sovereignty, faithfulness, and unconditional love. ${ }^{9}$ Throughout Old Testament history, the people of Israel have often gone far from God, returned to him, and then gone away again. The prophets were calling them to repent and to turn back to God. The prophet Isaiah foreshadowed the dynamics of God's relationship with His chosen ones in a prophecy, "I was found by those who did not seek Me, I became manifest to those who did not ask for Me.' But as for Israel He says, 'All the day long I have stretched out My hands to a disobedient and obstinate people"' (Rom. 10:20-21; cf. Isa. 65:1-2). Isaiah's prophecy was fulfilled in Jesus' incarnation, ministry, death, resurrection, and sending of the Holy Spirit. God's chosen ones (regardless of their ethnicity) were born from above, by the Holy Spirit (John 3:3-6).

In the parable of how we should always pray and never grow tired of it, (Lk. 18:1-8) Jesus points the believers to the reality of God defending "His elect who cry to Him day and night." Jesus is certain of God's unchangeable love and faithfulness, but he does question the love and faithfulness of the chosen ones. Thus, he asks the question. "However, when the Son of Man comes, will He find faith on the earth?" (Lk. 18:8). The apostle Paul emphasizes the fact that God's elect are all those who believe in Jesus Christ (Rom. 8:33-39), whose character was changed, and who live and act in accordance with God's Word.

Those Who are Sent. The New Testament places a strong emphasis on the Church as God's property being a community of people on God's mission. As their

9 The following quotes also point to God's people as God's elect: 1 Ch. 16:12-13; Ps. 105:5-6, 43; Isa. 65:22. 
owner, God sent them into the world, not to identify with the world, but to change the world. The mission of evangelizing the world which the Lord Jesus Christ has tasked his disciples with was written in all four Gospels (Mt. 28:18-20; Mk. 16:1418; Lk. 24:46-49; Jn. 20:21-22) and in Acts (Acts 1:8), and it was especially emphasized in the Gospel as recorded by Matthew, "And Jesus came up and spoke to them, saying, 'All authority has been given to Me in heaven and on earth. Go therefore and make disciples of all the nations, baptizing them in the name of the Father and the Son and the Holy Spirit, teaching them to observe all that I commanded you; and lo, I am with you always, even to the end of the age"' (Mt. 28:18-20).

These words of Jesus contain three crucial and inseparable unities: the declaration of Christ's authority, the command to make disciples, and the promise of Jesus' presence with the disciples. The Great Commission is a command to proclaim the Gospel, which includes preaching the Good News, witnessing from one's own experience and relationship with God, practical love for our neighbour as empowered by the power of the Holy Spirit, and the process of discipleship and growing into the Church.

Summary. The New Testament picture of the Church as God's people points to a community of believers who are owned by God, who need to be separate from the world, whom God will abide in, who will gladly witness about God being their personal God, and who will live and serve together according to God's will and in the power of the Holy Spirit. It's all those who have been sanctified in Christ, whom God has chosen, called, and made holy, and all those who call upon the name of Jesus Christ anywhere. As God's property, the Church is a community of people on God's mission. As their owner, God sent them into the world not to become one with the world, but to change the world with the Gospel.

\section{Picture From the Functions of the Human Body}

The Body of Christ. The New Testament picture of the Church as the Body of Christ may be the most familiar Biblical picture of the Church today. It is used in modern Evangelical Churches in order to emphasize the usage of spiritual gifts and house meetings of Christians. The picture of the human community as a body was a sociopolitical idea that was popular in the Hellenistic circles during apostle Paul's day (Hodgson 1988, 29-30; Peterlin 2010, 75-92). Paul has reshaped this popular picture and connected it to the crucified and resurrected Jesus Christ.

Although we can find the hints of Church being the Body of Christ in Romans and 1 Corinthians, as we well as in Luke's account of Paul's experience in Damascus (see Rom. 12:4-5; 1 Cor. 6:15-19; 12:12-27; Acts 9:5; 22:8; 26:15), the following passages explicitly describe the Church as the Body of Christ: 
"For just as we have many members in one body and all the members do not have the same function, so we, who are many, are one body in Christ, and individually members one of another" (Rom 12:4-5).

"Now there are varieties of gifts, but the same Spirit. And there are varieties of ministries, and the same Lord. There are varieties of effects, but the same God who works all things in all persons. But to each one is given the manifestation of the Spirit for the common good. For to one is given the word of wisdom through the Spirit, and to another the word of knowledge according to the same Spirit; to another faith by the same Spirit, and to another gifts of healing by the one Spirit, and to another the effecting of miracles, and to another prophecy, and to another the distinguishing of spirits, to another various kinds of tongues, and to another the interpretation of tongues. But one and the same Spirit works all these things, distributing to each one individually just as He wills."

"For even as the body is one and yet has many members, and all the members of the body, though they are many, are one body, so also is Christ. For by one Spirit we were all baptized into one body, whether Jews or Greeks, whether slaves or free, and we were all made to drink of one Spirit. For the body is not one member, but many. If the foot says, "Because I am not a hand, I am not a part of the body", it is not for this reason any the less a part of the body. And if the ear says, "Because I am not an eye, I am not a part of the body," it is not for this reason any the less a part of the body. If the whole body were an eye, where would the hearing be? If the whole were hearing, where would the sense of smell be? But now God has placed the members, each one of them, in the body, just as He desired. If they were all one member, where would the body be? But now there are many members, but one body. And the eye cannot say to the hand, "I have no need of you"; or again the head to the feet, "I have no need of you." On the contrary, it is much truer that the members of the body which seem to be weaker are necessary; and those members of the body which we deem less honorable, on these we bestow more abundant honor, and our less presentable members become much more presentable, whereas our more presentable members have no need of it. But God has so composed the body, giving more abundant honor to that member which lacked, so that there may be no division in the body, but that the members may have the same care for one another. And if one member suffers, all the members suffer with it; if one member is honored, all the members rejoice with it. Now you are Christ's body, and individually members of it. And God has appointed in the church, first apostles, second prophets, third teachers, then miracles, then gifts of healings, helps, administrations, various kinds of tongues. All are not apostles, are they? All are not prophets, are they? All are not teachers, are they? All are not workers of miracles, are they? All do not have gifts of healings, do they? All do not speak with tongues, do they? All do not interpret, do they? But earnestly desire the greater gifts. And I show you a still more excellent way" (1 Cor. 12:4-31). 
"And He put all things in subjection under His feet, and gave Him as head over all things to the church, which is His body, the fullness of Him who fills all in all" (Eph. 1:22-23).

"And He gave some as apostles, and some as prophets, and some as evangelists, and some as pastors and teachers, for the equipping of the saints for the work of service, to the building up of the body of Christ; until we all attain to the unity of the faith, and of the knowledge of the Son of God, to a mature man, to the measure of the stature which belongs to the fullness of Christ. As a result, we are no longer to be children, tossed here and there by waves and carried about by every wind of doctrine, by the trickery of men, by craftiness in deceitful scheming; but speaking the truth in love, we are to grow up in all aspects into Him who is the head, even Christ, from whom the whole body, being fitted and held together by what every joint supplies, according to the proper working of each individual part, causes the growth of the body for the building up of itself in love" (Eph. 4:11-16).

"For the husband is the head of the wife, as Christ also is the head of the church, He Himself being the Savior of the body" (Eph. 5:23).

"He is also head of the body, the church; and He is the beginning, the firstborn from the dead, so that He Himself will come to have first place in everything...

Now I rejoice in my sufferings for your sake, and in my flesh I [a]do my share on behalf of His body, which is the church, in filling up what is lacking [b]in Christ's afflictions" (Col. 1:18.24).

"Therefore no one is to act as your judge in regard to food or drink or in respect to a festival or a new moon or a Sabbath day - things which are a mere shadow of what is to come; but the substance belongs to Christ. Let no one keep defrauding you of your prize by delighting in self-abasement and the worship of the angels, taking his stand on visions he has seen, inflated without cause by his fleshly mind, and not holding fast to the head, from whom the entire body, being supplied and held together by the joints and ligaments, grows with a growth which is from God" (Col. 2,16-19).

What does it mean that the Church is the body of Christ? ${ }^{10}$ Under the inspiration of the Holy Spirit, apostle Paul develops a model of the Church as the body of Christ. To the Church in Corinth, he wrote, "Now you are Christ's body, and individually members of it" (1 Cor. 12:27). He wrote something similar to Romans,

10 Williams $(1992,66)$ points to two extremes in reference to the Church as the Body of Christ. One is a literal meaning, where the Church is Christ's physical body, which replaced His former physical body. The second error is viewing the Church as the Body of Christ only as a metaphor to refer to a gathered body of people, like a political body. 
"... so we, who are many, are one body in Christ, and individually members one of another" (Rom. 12:5). Through apostle Paul, the Holy Spirit declared the eternal and immutable truth that Jesus Christ is "the head of the church, He Himself being the Savior of the body" (Eph. 5:23); "He is also head of the body, the church" (Col. 1:18). ${ }^{11}$ What does that mean?

Williams $(1992,66)$ suggests three important observations: 1) a living relationship with Jesus; 2) mutual membership; and 3) serving entire mankind. The Church has a living connection with Christ - believers are in Christ. The Church consists of the "saints" and "faithful in Christ Jesus" (Eph. 1:1). The apostle Paul emphasizes this very well in Ephesians: in his Son, God the Father has chosen for himself believers in Jesus Christ before the creation of the world to be holy and blameless before him (Eph. 1:4). Since Jesus Christ is the head, and the Church is His body, the head gives body life. Being connected to the Head allows every member of the Body to have life, whether it is, humanly speaking, a more or less important member, big or small, visible or hidden. The Church and its members are spiritually dead without a life-giving relationship with Him. The Church and its members are always spiritually dead when they stop having a relationship with Jesus Christ - the living, almighty, omnipresent God - and start following their own theologies, traditions, policies, visions, and plans.

Christ's disciples are always directly connected to Jesus Christ, and they are available to him 24 hours a day. Without this unbroken connections with Jesus, their life begins to fade, which is primarily reflected in quitting worship, praise, proclaiming the Gospel, and serving in the family, Church, and society.

The easiest way to understand this spiritual process is when we compare it to the human body. I can remember a time when I worked at a mechanic's shop for a while. Some of us were doing some alterations on a truck. Suddenly, we heard a scream from the side room with a large machine for cutting sheet metal. We all ran to the room. One of our co-workers was not careful enough and the machine cut one of his hands in half, severing four of his fingers. The shop owner remained level-headed and he immediately took the part of the hand with the four fingers, put it in a plastic bag, filled it with ice, and took it along when the paramedics came. In the hospital, the doctor specialists spent several hours surgically

11 Here it's important to note that the Holy Spirit's statement through apostle Paul that "He is the Head of the Body, which is the Church" is a central truth for all Church models. It has happened during history that the Church model as the Body of Christ was neglected and replaced with the model of the Church as the people of God. In the people of God Church model, God and the people are crucial. Since, according to OT examples, which has the model of God's people rooted in it, God doesn't communicate with each individual but with a chosen leader, the leader of "God's people" (the Pope?) is considered to be the true leader, and the role of Jesus Christ is reduced to a merely ceremonial one. 
re-attaching the severed piece of the hand to its place and trying to restore the function to fingers. They attached the nerves and blood vessels, and they stitched the severed part of the hand back together, but they were unsuccessful in restoring life to the severed part of the hand. In the end, they had to remove the dead tissue (the part with the four fingers) from the living tissue. They threw away the dead tissue, and they went on to remedy the rest of the hand, with the thumb. The severed part of the hand, the one with the four fingers, died off, and the rest of the hand which was still connected with the head and body through blood vessels, nerves, muscles, and skin kept on living, although it was handicapped. The function of the severed fingers was only partially taken over by the thumb and the partial palm.

The favorite theological and preachers' exhortations for believers to be connected with Jesus Christ as the head and to ask Christ himself to show them how to live and act are often inapplicable in life. Why? Because they separate the head from the body and teach believers that they are the ones who need to connect with Christ and ask him for instructions for life and work. The fact is, not a single body (or part of the body) which is separated from the head has no life in it, and consequently neither the will or strength to ask the head, let alone to think about life or work. A body that is separated from the head is a dead body. A Church that is separated from Christ is a dead Church. A believer separated from Christ is a dead believer.

It is important to note that the connection of the hand with the head and body was manifold. The hand was connected by blood vessels, nerves, muscles, and skin with the forearm, which was then connected with the upper arm by the joint, which was then connected by joint with the shoulder, ... blood was reaching the hand through the upper arm and the forearm via the blood vessels, and nerves carried the commands from the head to the hand. In other words, the hand was directly connected to the head via nerves, and blood vessels circulated blood through it, while skin and muscles connected it to other parts of the body via the forearm and the upper arm.

Two things are important for life, growth, and activities of the Church as the Body of Christ: First, the direct connection via "nerves" of every part of the body with the Head, Jesus Christ, who governs the entire body and every part of it, even the tiniest one. If and when this connection in the body is severed, the part that is not connected to the head remains paralyzed. ${ }^{12}$ Second, the direct connection with the bloodstream which provides food and energy for life and working of every member. The spiritual bloodstream of the Church is the prea-

12 See the example of Joni Eareckson Tada, who was left paralyzed from head down (http://joniearecksontadastory.com). 
ched Word of God, which feeds and empowers every member through the Holy Spirit, enabling them to do the works of love which God prepared beforehand (cf. Eph. 2:10), both for the individual members of the Body of Christ, and the local fellowship, and the regional and global Church.

If we have these two things in mind, we will be able to observe our own spiritual condition and the condition of the Church more clearly. If a member of Christ's Body is not directly connected to Christ, that member is paralyzed (defunct), as are all the other members which depend on that member in the local fellowship as a Body of Christ, or are connected through it via nerves (i.e., spiritual bonds). Breaking a direct connection with Christ results in the believer's spiritual paralysis, and through him or them, the paralysis of the parts of the Body - Church - which depend on its connection. If the pastor is not directly connected to Christ, the local fellowship which he is leading will be "paralyzed," i.e., ineffective. This fellowship will remain being a Body of Christ, but it will be paralyzed, defunct. If the Church elders are not directly connected with Christ, the part of Church's ministry which depends on the elders will become defunct.

The break in connection of the believers in the "bloodstream" of the entire body with Jesus Christ as the Head will result in dying off. The creative Word of God is the content of the bloodstream, which constantly flows through the Body of Christ, keeping all the members alive, empowering them for performing all the functions and works of love which God the Father had prepared beforehand through Jesus Christ so we can abide in them (Eph. 2,10). Preaching the Word of God is like the bloodstream through which the Word, in the power of the Holy Spirit, reaches every member of Christ's Body. It is now much easier to understand Jesus' command, "Go into all the world and preach the gospel to all creation" (Mk. 16:15). With this command, Jesus established the "bloodstream" in his Body, the Church. The Word of God is food, the energy for life, the fundamental bearer of life.

The fundamental question is: what exactly is the Church, what should it be, and then what should the Church be doing? What does it mean to be a Church? The Holy Spirit clearly points out, "For we are His workmanship, created in Christ Jesus for good works, which God prepared beforehand so that we would walk in them" (Eph. 2:10). God created us for the good deeds which He prepared for each believer. Those are not the works which have been thought out or invented by top theologians, Church Fathers and dignitaries, saints of any kind, or famous "anointed" preachers and individuals. Those are the works which God has thought out and prepared for each individual believer in accordance with his plans. These plans are fully or partly revealed by God the Father to the believer in Jesus Christ through the Holy Spirit. God gives believers instructions, wisdom of understanding or the peace of not understanding in obedience for these plans and prepared works, and the strength to do the works of love. In this process, 
each individual member (believer) of the body of Christ is fully dependant on Jesus Christ alone. As the head, Jesus Christ is leading his Church, just like the brain and the central nervous system give instructions to the physical body. The Church, as the Body of Christ, depends completely on Christ, just like any other member of Christ's Body. However, it is good to remember here that, despite its spiritual relationship with Christ, the Church "always remains sinful while it is on this earth" (Williams 1992, 67).

As the Body of Christ, the Church was established and it still exists for the purpose of obeying the will of its Head, Jesus Christ. Since the Church is called to submit to Christ, believers are called to "be subject to one another in the fear of Christ" (Eph. 5:21-24). Every believer is a member of Christ's body, and they all depend on one another, "For the body is not one member, but many" (1 Cor. 12:14). The Church is not an institution, a social organization, or a gathering place for like-minded people. The Church is a living organism (a body) made up of believers who were born of the Holy Spirit (cf. Jn. 3:3-8), which is governed and lead by Jesus Christ. It is a living organism which has received God's life and is empowered by the Holy Spirit.

The Church is comprised from different members, who have different functions and purposes, just like different parts of the human body do. Just like every part of the human body, each Church member also has a specific function and agency in the life of the entire congregation. "For even as the body is one and yet has many members, and all the members of the body, though they are many, are one body, so also is Christ" (1 Cor. 12:12). All believers in the Church are mutually connected through the Word of God and the Holy Spirit, who gives out and distributes gifts and ministries in the local fellowship of believers in accordance with God's plan for that fellowship, and God's prepared good works in which each individual believer should walk (cf. Eph. 2:10). In order for the Church to know about God's plan for itself, the Church leadership needs to maintain a constant living relationship with its Head: Jesus Christ. If believers want to know what sort of good works they were created for and what is it that God had prepared for their life beforehand (cf. Eph. 2:10), they need to have a living relationship with Jesus Christ.

Christ, as the Head, governs and feeds the body, and the Holy Spirit gives it life and energy. The Bible puts a strong emphasis on the relationship between all the body members, as well as on the differences and equality in unity. Each member needs to be functional (cf. 4:4, 15-16). It is a challenge for the Church to be a healthy body in which all members are doing their part. All members need to be in a conscientious fellowship with God, and out of that fellowship they need to contribute to the life and fellowship of the Church while at the same time respecting and accepting the fellowship of other Church members with God and their serving and works on the basis of their relationship with God. 
The Church is called to obey God's will in its relationship with other people as well. The Church is not called to serve the world or people, but only God. Of course, serving God will often be reflected in doing good for other people. Those are God's works in which the Church as a community and individual believers all participate in. Since Christ is the Head, and the Church is his body, it is and must be a servant, just like Christ was. Paul emphasizes his own example, "who, although He existed in the form of God, did not regard equality with God a thing to be grasped, but emptied Himself, taking the form of a bond-servant, and being made in the likeness of men. Being found in appearance as a man, He humbled Himself by becoming obedient to the point of death, even death on a cross" (Phil. 2:6-8). The Church, as the body of Jesus Christ, needs to continually serve just as he served. It needs to be the next serving Church in the world, which will serve the physical, emotional, and spiritual needs of people.

Just like the Church is completely dependent and subjected to Jesus Christ, so the members of his body are dependent on each other and mutually responsible in their actions (Williams 1992, 71). As the Body of Christ, the Church needs to stop dealing with itself and start serving God's purposes in the world to a much greater extent.

Paul describes our unity in the Body of Christ as the work of the Spirit, who is creating a new mankind. This new mankind operates as the Body of Christ on earth, under Christ's leadership through the permanent work of the Spirit who gives us gifts, guides us, and shows mercy to the Church (Gelder 2001, 110). "For just as we have many members in one body and all the members do not have the same function, so we, who are many, are one body in Christ, and individually members one of another" (Rom. 12:4-5). This means that the nature of the Church includes interdependence among all members. This interdependence is the function of the variety of spiritual gifts which have been given through the Spirit for the benefit of all members, as well as the works of love which God had prepared beforehand for every Christian and for every community of believers. This is why the Church, as the Body of Christ, needs to live as a new community in a dynamic, gifts-based, active interdependence.

The Church is the Body of Christ: a living organism. Just like our physical bodies are made up of various parts such as arms, legs, ears, and eyes, so is the Body of Christ made up of various members. Each member is important for the proper working and growth of the body. Each part of our physical body is important and necessary for the body to work. However, not every part of the body is visible, nor do we understand the functions of every part of our physical bodies. We are not even aware of some of our parts of our physical body. And yet, our physical body is working perfectly in spite of our ignorance. God created it that way.

The Church is a Body with mutually accepted members which work toget- 
her according to God's plan and will by doing the works of love which God had prepared beforehand so that each believer would abide in them (cf. Eph. 2:10). The works of love which God prepared for every born-again believer are directly revealed by God to each believer, directly or indirectly. The unity of believers and the fellowship of believers are not in a single organization nor in an agreement between Christian organizations, but in a unique relationship of the born-again believer with the Head: Jesus Christ, and the mutual relationship with those who obey the Word of God together in the Body of Christ.

Every person in the Body of Christ is important. We all need to serve with our gifts and ministries received by God through the Holy Spirit, regardless of how significant or insignificant we or others think they are. Some gifts and ministries in the Body of Christ are very obvious, such as mouth, eyes, arms, and legs on our body. Other gifts and ministries in the Body of Christ are hidden from human eyes, such as the heart, lungs, liver, or kidneys. It is impossible to live without the hidden parts of the body. Without the visible parts of the body life is difficult and serving is impossible. The healthiness or unhealthiness of the Church can be seen in its life and activities. The Church is healthy when it lives and obeys the will of God in the power of the Holy Spirit. The Church is ill when it fails to recognize and obey the will of God in the power of the Holy Spirit. The Church's sickness can be manifested in numerous different ways. In many fellowships of believers, human desires, programs, plans, and strategies come first, and God's will is not even considered, sought, nor obeyed. ${ }^{13}$ Believers with God's gifts and ministries are inactive and ineffective. ${ }^{14}$

13 Modern pastors, preachers, priests, bishops, and fellowship leaders often tie people, whom God the Father connected to the Church of His Son Jesus Christ, to themselves and their organization, denomination, or institution, instead to Christ and His body. Born-again believers very quickly become assimilated in a fellowship which operates on the model made by the pastor, or the one the pastor adopted from his denomination. People who are connected to the Body by God are often appropriated by pastors, who go on to make them into their own disciples, instead of disciples of Christ. They teach them to do everything that he and his denomination are teaching, even though Jesus commanded them to teach the new believers to do everything that He commanded them. Soon enough, people learn how to live and work according to pastor's expectations, instead of the expectations of Jesus Christ through the Holy Spirit.

14 When a person dies, especially if they're young, it's become customary to donate their healthy organs to a person in need. I've seen something similar after the "death" of local churches. Their healthy members take their functioning gifts and ministries, and move to other healthy Churches, or at least Churches that they believe are healthy. However, there are also foul extremes happening in the world today, particularly in the human organ market. Sick rich people who need an organ transplant usually don't care how they get the organs they need. And one can buy anything, even organs for transplant. Media reports often reveal that, on top of the donation system for healthy and functional organs after a person's sudden death, there is also 
Each local Church is a part of the Body of Christ. Our individual ministries and gifts in the local Church are very important, because God prepared them and gave them to the Church. Only heaven will reveal how many churches fell apart because somebody who was placed in a Church in order to serve with their ministry or gift given by the Holy Spirit has neglected their ministry and/or gift.

The picture of the Church as the Body of Christ includes: a living relationship with Jesus Christ; submission of all the members to the head of the Body - Jesus Christ; unity of the body with the head, Jesus Christ; diversity of ministries and gifts which vary in function, effectiveness, strength, and honor, but are at the same time all important for the Body; mutual interdependence and responsibility of every member; and serving God in the world together.

Summary. The picture of the Church as the Body of Christ shows that the Church is a living organism, whose Head is Jesus Christ. The member that belong to this body are all those who have a living relationship with Jesus Christ and who obey Him. The Church is a living organism (a body) comprised of believers who were born of the Holy Spirit (cf. Jn. 3:3-8); who is governed and lead by Jesus Christ. It is a living organism in unity with the Head - Jesus Christ - which has received God's life and is empowered by the Holy Spirit. The Church is a fellowship of believers with different ministries and gifts which vary in function, effectiveness, strength and honor, but at the same time they are all important for the Body. The members are connected together, interdependent, and responsible in serving God in the world together.

\section{Pictures from Premarital, Married, and Family Life}

Christ's Betrothed. The picture of the Church as Christ's betrothed ${ }^{15}$ in the New Testament is summarized in Ephesians in this statement, "just as Christ also loved the church and gave Himself up for her" (5:25). Jesus Christ has shown His ultimate love for the Church by giving his life for it.

an organ market where living people sell their organs for various reasons. In that market there are examples where people are intentionally killed so their organs could be used on a person with better monetary power. I've experienced something similar as a Church pastor in the spiritual area. In the Church I served in during the 1980's and 1990's, representatives of growing and financially powerful churches and para-church organizations from the West would come in and, with the excuse that they wish to help our Church, they would spend several months getting to know the people and soon after they would take away some of the best people who worked as members of the Body of Christ - the local Church. 
The picture of the Church as the betrothed was familiar and close to the Jewish nation for centuries. The prophet Isaiah confirmed this reality of the Israelites, "For your husband is your Maker, whose name is the Lord of hosts" (Isa. 54:5). Jeremiah reminds the Israelites on God's behalf of their engagement, love, faithfulness, and obedience, "I remember concerning you the devotion of your youth, the love of your betrothals, your following after Me in the wilderness, through a land not sown" (Jer. 2:2). The prophet Ezekiel, when he describes the relationship between God and His betrothed/wife ${ }^{16}$ (the Israelites), emphasizes God's central act of love, "I also swore to you and entered into a covenant with you so that you became Mine', declares the Lord God" (Ez. 16:8). If we read the entire prophetic scripts which relate to God's people as God's betrothed/wife, it is easy to see that Israel kept repeating its unfaithfulness and immorality over and over again (cf. Jer. 3:20; Ez. 16:15-63). The Old Testament picture of Israel as God's betrothed/wife was complemented by God's Word through the prophet Hosea: "It will come about in that day,' declares the Lord, 'That you will call Me Ishi... Yes, I will betroth you to Me in righteousness and in justice, in loving kindness and in compassion, and I will betroth you to Me in faithfulness. Then you will know the Lord"' (2:16-20).

The New Testament emphasizes that Jesus Christ is betrothed to his Church. When some people asked Jesus why do disciples of John and the pharisees fast and his do not, Jesus replied to them, "While the bridegroom is with them, the attendants of the bridegroom cannot fast, can they? So long as they have the bridegroom with them, they cannot fast. But the days will come when the bridegroom is taken away from them, and then they will fast in that day" (Mk. 2:18-20; cf. Mt. 9:14-15; Lk. 5:33-35). John the Baptist emphasized this truth strongly, "He who has the bride is the bridegroom" (Jn. 3:29). This statement reveals that Jesus Christ is the groom, and Jesus' disciples as a group are the bride.

The parable about the king who prepared a feast for his son (Mt. 22:1-14) complements the picture of the Church as Christ's betrothed. Just like this king, God the Father prepared a wedding feast for his Son Jesus Christ. He invited the Israelites as wedding guests. However, they refused to come. God then invited all the people that His servants were able to find on crossroads. This parable clearly tells us that Christ's betrothed is made up of all those people who have and who will respond to God's invitation to the wedding feast. Those who have responded to the invitation need to be watchful, so they would be ready for their groom when He comes (cf. Mt. 25:1-13).

In his epistles, the apostle Paul uses the picture of Jesus as groom and the Church as the bride. To the Corinthians he wrote, "For I am jealous for you with

16 The terms "betrothed" and "wife" ("bride" and "wife") are used interchangeably in the Bible and in Jewish culture. Both terms are used for the Church and its relationship with Christ. 
a godly jealousy; for I betrothed you to one husband, so that to Christ I might present you as a pure virgin" (2 Cor. 11:2). In Ephesians, Paul describes the relationship between a husband and wife comparing it to the relationship between Christ and the Church (Eph. 5:21-33). At the center of this relationship we find the selfless love of Jesus Christ towards his betrothed, the Church.

Revelation tells us about the finale of the royal wedding feast, "And a voice came from the throne, saying, "Give praise to our God, all you His bond-servants, you who fear Him, the small and the great.' Then I heard something like the voice of a great multitude and like the sound of many waters and like the sound of mighty peals of thunder, saying, 'Hallelujah! For the Lord our God, the Almighty, reigns. Let us rejoice and be glad and give the glory to Him, for the marriage of the Lamb has come and His bride has made herself ready"' (Rev. 19:5-7). Revelation completes the picture of the Church as Christ's bride with these words, "Blessed are those who are invited to the marriage supper of the Lamb" (Rev. 19:9) and it invites everyone to join the Church as the bride, "The Spirit and the bride say, 'Come.' And let the one who hears say, 'Come.' And let the one who is thirsty come; let the one who wishes take the water of life without cost" (Rev. 22:17).

The picture of the Church as the bride of Christ tells us that the Church - the bride - is united in love with Christ, is called to faithfulness and purity, and to life in expectation of the Groom (cf. Williams 1992, 74-77). Let us review each of these connections.

1. The Church is United with Christ in Love. What does that mean? God the Father uses pictures which are close to people and easily recognizable in order to explain and bring closer the truth about the relationship between Jesus Christ and the Church. When He created the first man and the first woman, God said, "and they shall become one flesh" (Gen. 2:24). This picture of the union between the groom and the bride before marriage and the husband and wife in marriage has been deeply instilled in everybody's memory for millennia, and it's partly the case today as well. God, the inventor of love and creator of relationships has enabled all people to be loved and to love. Love creates a unique relationship between people: we dream about love, we wait for love patiently, we enjoy love, we create because of love. The apostle Paul summarized the truth about love, "Love is patient, love is kind and is not jealous; love does not brag and is not arrogant, does not act unbecomingly; it does not seek its own, is not provoked, does not take into account a wrong suffered, does not rejoice in unrighteousness, but rejoices with the truth; bears all things, believes all things, hopes all things, endures all things" (1 Cor. 13:4-7). He then pointed out the eternal truth, "Love never fails" (1 Cor. 13:8).

The apostle Paul applies the picture or the relationship between Jesus Christ 
and the Church to the relationship between the husband and the wife. That is why he writes, "and be subject to one another in the fear of Christ. Wives, be subject to your own husbands, as to the Lord. For the husband is the head of the wife, as Christ also is the head of the church, He Himself being the Savior of the body" (Eph. 5:21-23). He goes on to add, "Husbands, love your wives, just as Christ also loved the church and gave Himself up for her, so that He might sanctify her, having cleansed her by the washing of water with the word, that He might present to Himself the church in all her glory, having no spot or wrinkle or any such thing; but that she would be holy and blameless" (Eph. 5:25-27).

The unity between Christ and the Church is personal and spiritual, and not corporate and organizational. God's Word clearly states this, "But the one who joins himself to the Lord is one spirit with Him" (1 Cor. 6:17). This unity is a reflection of the relationship between the body and the head in love which was based on a sacrifice. The relationship between the bride (the Church) and the groom (Christ) is not based on some sentimental infatuation which fades and disappears after a while, but is instead based on the impassable, eternal, giving love which was affirmed through the death and resurrection of the Son of God. The apostle Paul exclaimed, "For the love of Christ controls us, having concluded this, that one died for all, therefore all died; and He died for all, so that they who live might no longer live for themselves, but for Him who died and rose again on their behalf" (2 Cor. 5:14-15). The Church, as the bride of Christ, thus lives in unity with Christ, who died for her.

2. Jesus Christ Called the Church to be Holy and Blameless. The apostle Paul sets the call to holiness and blamelessness in love as a standard for marriage. An example of such love is the love Jesus Christ has for the bride, the Church, "Husbands, love your wives, just as Christ also loved the church and gave Himself up for her, so that He might sanctify her, having cleansed her by the washing of water with the word, that He might present to Himself the church in all her glory, having no spot or wrinkle or any such thing; but that she would be holy and blameless" (Eph. 5:25-27). The Church has already been made clean ${ }^{17}$ but as long as it remains in the world, it has the need to be continuously cleansed and sanctified.

Williams $(1992,76)$ points out that this kind of faithfulness and purity has several aspects. First, the purified Church can remain holy and blameless only if it remains faithful to its only groom - Jesus Christ. This requires exclusive devotion to Jesus. The apostle Paul emphasizes, "for I betrothed you to one husband, so that to Christ I might present you as a pure virgin" (2 Cor. 11:2). The Bible calls any kind of flirting with the world and the systems and values of this world

17 This probably implies the baptism of adults who have repented for their sins, were baptized by water, and have received the Word of God. 
idolatry and adultery. Therefore, the Word of God warns Christians, "You adulteresses, do you not know that friendship with the world is hostility toward God? Therefore whoever wishes to be a friend of the world makes himself an enemy of God." (Jas. 4:4). A Christian who is faithful to Jesus Christ lives in the world but is not and doesn't like to be a friend of the world.

Second, faithfulness and purity include a firm grasp of the truth in Jesus Christ. Faithfulness to Jesus Christ does not only imply faithfulness to him as a person but also to the truthfulness of the teaching he introduces into the believer's life. So it is not possible to remain faithful to Jesus Christ if we deny any part of the teaching with our words or actions, especially the parts about his divine nature, his relationship with God the Father, power, authority, incarnation, resurrection, and omnipresence.

Third, faithfulness and purity imply a holy and righteous life. The Word of God gives us an insight into the future, at the time of the marriage of the Lamb, the wedding of Christ the King and the Church, "Let us rejoice and be glad and give the glory to Him, for the marriage of the Lamb has come and His bride has made herself ready. It was given to her to clothe herself in fine linen, bright and clean; for the fine linen is the righteous acts of the saints" (Rev. 19:6-8). Preparing the Bride and clothing her in fine linen, bright and clean points to the acts of the saints which were done during their earthly life. Therefore, the Church, as the faithful bride of Christ, needs to live a holy life, doing righteous works prepared by God (cf. Eph. 4:10), which the Word of God commands us to do; works which are pleasing to God and which bring him glory.

3. Living in Expectation of the Groom. The Church is waiting for the Groom Jesus Christ - to come back. The Church of today can only partly experience and enjoy the Groom's love. The fullness of joy, love, and fellowship is yet to come (cf. Rev. 19:7). In this excited expectation, the bride maintains her consecration, faithfulness, and purity for her Groom.

God's Family. The picture of the Church as God's family is strongly emphasized in Jesus' teaching and actions. The Word of God and the Holy Spirit form a new reality and new relationships in a person. Jesus takes the usual family relationships rooted in God's people Israel, and brings significant changes into them, setting new standards. In the Church, the affiliation to the family is not measured by the purity of the "blood bond," but by obeying God's will, "And stretching out His hand toward His disciples, He said, 'Behold My mother and My brothers! For whoever does the will of My Father who is in heaven, he is My brother and sister and mother"'(Mt. 12:49-50).

This new standard does not apply to all families, but just to God's family. So who belongs in God's family? Jesus' brothers, sisters, and mother are only those whose Father is God, who know the will of the Father and obey it. The apostle 
Paul applies this Jesus' standard to the Church, which according to God's plan includes both Israel and pagans into God's family. When he interpreted this reality to the Church in Ephesus, apostle Paul exclaimed, "For this reason I bow my knees before the Father, from whom every family in heaven and on earth derives its name" (Eph .3:14-15).

God's family lives according to God's standards, which makes it significantly different from all other families and their standards for life. That is why apostle Paul warns the Corinthians, "Do not be bound together with unbelievers; for what partnership have righteousness and lawlessness, or what fellowship has light with darkness? Or what harmony has Christ with Belial, or what has a believer in common with an unbeliever?" (2 Cor. 6:14-15). In order for God's family to remain God's family, it needs to separate itself from the unbelievers continually. The call to be separated from non-believers and to live in God's family echoes strongly both in the Old and New Testaments (cf. Isa. 52:11; Rev. 18:4). Apostle Paul is especially aware of it when he writes to Corinthians, "Therefore, come out from their midst and be separate,' says the Lord. 'And do not touch what is unclean; and I will welcome you. And I will be a father to you, and you shall be sons and daughters to Me,"' says the Lord Almighty" (2 Cor. 6:17-18).

The New Testament establishes love as a standard of living and the fundamental connection in God's family. Jesus said to his disciples, "If you love Me, you will keep My commandments" (Jn. 14:15). He went on to say, "He who has My commandments and keeps them is the one who loves Me; and he who loves Me will be loved by My Father, and I will love him and will disclose Myself to him" (Jn. 14:21). When Judas asked him, "Lord, what then has happened that You are going to disclose Yourself to us and not to the world?' Jesus answered and said to him, 'If anyone loves Me, he will keep My word; and My Father will love him, and We will come to him and make Our abode with him. He who does not love Me does not keep My words; and the word which you hear is not Mine, but the Father's who sent Me"' (Jn. 14:22-24).

The love for God the Father and the Son Jesus Christ is not manifested just by professing the faith, but by doing God's will and his commands. Christians who obey the will of God will be rejected and hated by nonbelievers first of all (i.e., the world), and then by nominal believers as well (so-called "Christians") who use the name, but do not know God nor his will, so they do not even know what is it they are supposed to be doing. The apostle Paul emphasizes this strongly:

"Do not be surprised, brethren, if the world hates you. We know that we have passed out of death into life, because we love the brethren. He who does not love abides in death. Everyone who hates his brother is a murderer; and you know that no murderer has eternal life abiding in him. We know love by this, that $\mathrm{He}$ laid down His life for us; and we ought to lay down our lives for the brethren. 
But whoever has the world's goods, and sees his brother in need and closes his heart against him, how does the love of God abide in him? Little children, let us not love with word or with tongue, but in deed and truth" (1 Jn. 3:13-18).

When it comes to maintaining good interpersonal relationships inside God's family, Paul exhorts Timothy, "Do not sharply rebuke an older man, but rather appeal to him as a father, to the younger men as brothers, the older women as mothers, and the younger women as sisters, in all purity" (1 Tim. 5:1-2).

Summary. The Biblical pictures from premarital (the fiancé and fiancee), marriage (husband and wife), and family (father, mother, brother, and sister) life point us to the scope, dynamics, and quality of relationships in the Church as the bride of Christ and God's family. The picture of the Church as the bride of Christ reveals that the Church, as the bride, is united in love with Christ, is called to faithfulness and purity of living in expectation of the Groom. The picture of the Church as God's family shows that the Word of God and the Holy Spirit create a new reality and new relationship in a person, at the center of which is love. Jesus takes the usual family relationships and changes them significantly, setting up some new standards. Belonging to the Church family is not measured by the purity of the bloodline, but by obeying God's will.

\section{Pictures from Architecture}

The Scriptures use plenty of pictures from the world of architecture in order to emphasize the architectural reality of the Church. The Church is God's building (1 Cor. 3:9), God's temple (1 Cor. 3:16-17), spiritual house (1 Pt. 2:4-5), God's house (1 Pt. 4:17; Heb. 3: 3-6, and 1 Tim. 3:15), a pillar and support of truth (1 Tim. 3:14-15), God's dwelling place in the Spirit (Eph. 2:22). These pictures offer an insight into the relationship between God as the owner and the main "architect" of the Church, and believers as God's co-workers in building, and as building material. The pictures point to God the Father as the owner of the building, to Jesus Christ as the foundation of the house, to the process of house building, the selection and preparation of the building material, to behaviour in the house and ultimately, to the judgment over the house.

Ownership Over the Building. The Church is God's property, and the believers who are part of it are God's co-workers, God's building (1 Cor. 3:9). The apostle Paul then instructs the Corinthian Church, "Do you not know that you are a temple of God and that the Spirit of God dwells in you? If any man destroys the temple of God, God will destroy him, for the temple of God is holy, and that is what you are" (1 Cor. 3:16-17). God is the only "architect" of his building, the Church. Man cannot and must not interfere with God's project. 
Jesus Christ is the Builder. When the apostle Peter stated, "You are the Christ, the Son of the living God," Jesus said that he would build his Church on that rock (i.e. proclamation) (Mt. 16:15-18).

The Foundation of the Church as the Building is Jesus Christ. He said, "Therefore everyone who hears these words of Mine and acts on them, may be compared to a wise man who built his house on the rock" (Mt. 7:24). In order to understand this rock, we need to listen to and obey Jesus' words. It is in that context that we can understand Peter's proclamation of the revelation received from the heavenly Father. To the words, "You are the Christ, the Son of the living God," Jesus responds, "I also say to you that you are Peter, and upon this rock I will build My church (Mt. 16:15-18). Peter's not the rock; instead, it is his proclamation that Jesus is the Christ, Son of the living God.

Jesus Christ as the person and the Word is the original foundation and the cornerstone. His teaching and works were continued by those whom the Father gave to him (Jn. 17:6,9,11); they have recognized that everything that Jesus had given them, he gave them from the Father, because the words Jesus received from the Father, he gave to them (Jn. 17: 6-8). Therefore, the apostle Paul emphasizes that the foundation is the teaching of the apostles and the prophets which was received from Jesus Christ. He claimed that "no man can lay a foundation other than the one which is laid, which is Jesus Christ" (1 Cor. 3:11). He went on to say, "So then you are no longer strangers and aliens, but you are fellow citizens with the saints, and are of God's household, having been built on the foundation of the apostles and prophets, Christ Jesus Himself being the corner stone, in whom the whole building, being fitted together, is growing into a holy temple in the Lord, in whom you also are being built together into a dwelling of God in the Spirit" (Eph. 2:19-22).

Believers are Working Together with God as He's building the Church. The apostle Peter is instructing the believers to come to Jesus and to become built into a spiritual House as living stones (cf. 1 Pt. 2:4-5). Paul, on the other hand, emphasizes that the foundation for the Church has been set, and that is Jesus Christ. This is the foundation that every believer builds on with their works:

"According to the grace of God which was given to me, like a wise master builder I laid a foundation, and another is building on it. But each man must be careful how he builds on it. For no man can lay a foundation other than the one which is laid, which is Jesus Christ. Now if any man builds on the foundation with gold, silver, precious stones, wood, hay, straw, each man's work will become evident; for the day will show it because it is to be revealed with fire, and the fire itself will test the quality of each man's work. If any man's work which he has built on it remains, he will receive a reward. If any man's work is burned up, he will suffer loss; but he himself will be saved, yet so as through fire" (1 Cor. 3:10-15). 
Each believer chooses and prepares their own material for building (works and relationship), and everyone's works will be brought into the light. That is why the apostle Paul instructs Timothy, "I am writing these things to you, hoping to come to you before long; but in case I am delayed, I write so that you will know how one ought to conduct himself in the household of God, which is the church of the living God, the pillar and support of the truth" (1 Tim. 3:14-15).

In accordance with God's Word through the apostle Peter, God's house is only made up of those who obey God's Gospel (1 Pt. 4:17) and it is with them that God's judgment begins. Some of them who have limited vision of the Gospel tend to reduce obedience to the Gospel only to the salvation message. However, salvation is just a small and initial part of the magnificent Gospel, which reflects God himself. Therefore, those who disobey the Gospel, disobey God himself. Being saved is just the initial act of obedience to the Gospel; it is just an inaugural act of submission to God's will. But a real disciple who is fully dedicated must offer their entire life to submission and obedience to God. The judgment begins with Christ's disciples in his Church.

Summary. Pictures from the world of architecture give us an insight into the relationship with God as the owner and the main "architect" of the Church, and the believers as God's coworkers in building, and as building material. These pictures point to God as the owner of the house, Jesus Christ as the foundation of the house, to the process of building of the house, the selection and preparation of the building materials, to behaviour in the house and ultimately, to the judgment over the house. The emphasis is on God's ownership of the Church. God the Father as the owner of the building - the Church - has appointed Jesus Christ as the foundation, and he called the believers to become living rocks which are being built into the building, and to build on it with their works.

\section{Pictures from the Agricultural World}

Jesus used pictures and parables from agriculture: about the sower (Mt. 13:1-9, 18-23), tares (Mt. 13:24-30, 36-43), mustard seed (Mt. 13:31-32), and the harvest (Jn. 4:35-38).

In the parable of the sower, Jesus teaches us about different types of soil and the processes of accepting the Word and variations in fruitfulness in proclaiming the Gospel. The Gospel needs to be abundantly proclaimed, aware that people will accept it in various ways, and according to the way it is received it shall bear such fruit.

In the parable of the tares (Mt. 13:24-30, 36-43), Jesus points to the real condition of the Church as a field. The good seed has been sown, the Church has proclaimed the Word, and then it rests. And while the Church rests from its evan- 
gelistic endeavors, the enemy comes and sows the tares in the middle of the wheat and then leaves. The Church does not notice it immediately, but only once the crops have grown and their ears have been formed, the tares become noticeable then. The Church notices the tares and starts asking Lord Jesus questions such as, Why? Where from? What shall we do with the tares? Jesus begins teaching them again. Tares need to be removed during sowing, not during growth and ripening. Why? Because if we pull the tares while the wheat grows, we could pull the wheat with it as well.

In the parable of the mustard seed (Mt. 13:31-32), Jesus emphasized the power of the seed. Even though the mustard seed is the smallest of all seeds, once it grows it becomes bigger than all other vegetables, and it develops into a tree which serves the birds of the heavens. The Word of God is like the mustard seed: small and insignificant. It holds in itself the power to grow and to bring fruit. The Word of God does not return to God fruitless, but it does what God wanted and it factualizes the reason it was sent for (cf. Isa. 55:10-11). The Church is called and sent to proclaim the Word of God to the world, and the fruitfulness of the proclaimed Word is God's responsibility. Since Satan cannot stop God in his creative fruitfulness, he is surely trying to stop the Church from proclaiming (sowing) the Word.

By using the phrase "one sows, another reaps," Jesus emphasizes the reality of the fields being ready for the harvest. He is the master of the sowing and the harvest, and believers who are obedient to him work together and rejoice together, some as sowers and others as harvesters (cf. Jn. 4:35-38).

The apostle Paul applies well known pictures from agriculture in order to point out the interdependent processes in God's Kingdom. In the picture of the Church as God's field, the emphasis is God who is also the owner, the sower, and the one who makes the seed grow and develop into the fruit. People are only working together with God. However, since people always like to take the credit for successes in the Church, Paul points them towards God as the only one who deserves credit, "I planted, Apollos watered, but God was causing the growth. So then neither the one who plants nor the one who waters is anything, but God who causes the growth. Now he who plants and he who waters are one; but each will receive his own reward according to his own labor. For we are God's fellow workers; you are God's field, God's building" (1 Cor. 3:6-9). The owner of the field is God, who has prepared everything for the sowing and the harvest. The field is the world, and the seed is God's Word. God has entrusted the preparation of the field to believers, and He had already prepared the seed. Believers need to "plow and dig" into the world to prepare it for receiving the seed of the Word. Life is contained in the seed, and not in plowing and digging.

Summary. Pictures from agriculture, and especially the picture of the Church 
as God's field, emphasize that God is simultaneously the owner, the sower, and the one who allows the seed to grow and develop into the fruit. Humans are just God's co-workers. God is the owner of the field, the world is the field, and the seed is the Word of God. God has prepared the seed and has entrusted believers with preparing the field. Believers were sent to "sow" the seed: the Word. God makes the seed grow and be fruitful, and aside from sowing, believers are also included in the harvest and the celebration with sowers, harvesters, and the field owner.

\section{Pictures from Cattle Breeding and Fishery}

In the Bible, God uses pictures from cattle breeding and fishery in order to emphasize those elements in Church life which are insufficiently emphasized by other pictures.

The Church as a Flock. In the Old Testament, God repeatedly revealed Himself as a shepherd who takes care of Israel (Gen. 49:24; 2 Sam. 7:7; Ps. 80:1; Jer. 31:10; Ez. 34:16). Israel would emphasize this revelation on special occasions, "So we Your people and the sheep of Your pasture will give thanks to You forever; to all generations we will tell of Your praise" (Ps. 79:13). The Psalmist also emphasized it through his calls to worship God, "Come, let us worship and bow down, let us kneel before the Lord our Maker. For He is our God, and we are the people of His pasture and the sheep of His hand" (Ps. 95:6-7; cf. Ps. 100:3). The prophet Micah uses the picture of sheep in the pen and a flock in the pasture in order to describe the restored Israel, "I will surely assemble all of you, Jacob, I will surely gather the remnant of Israel. I will put them together like sheep in the fold; like a flock in the midst of its pasture they will be noisy with men" (Micah 2:12).

Jesus Christ referred to His disciples as a little flock, "Do not be afraid, little flock, for your Father has chosen gladly to give you the kingdom" (Lk. 12:32). Jesus uses the picture of the flock and the shepherd to emphasize that the flock is made up of the few who follow Him. And according to Jesus' words, even those few will run away, "You will all fall away because of Me this night, for it is written, 'I will strike down the shepherd, and the sheep of the flock shall be scattered" (Mt. 26:31; cf. Zech. 13:7).

Jesus emphasized that he is the Good Shepherd who gives his life for his sheep (Jn 10:11,15). He knows his sheep, and his sheep know him (Jn. 10:14). He is leading all the sheep and they are following Him because they know his voice (Jn. 10:4). He emphasized that his flock consists of all those who hear his voice (both Israelites and pagans) and follow him, and that there is only one flock and he is its only shepherd.

The apostle Paul used the picture of the flock and shepherd in order to warn the Church elders in Ephesus to watch themselves and over all the flock over 
which the Holy Spirit appointed them as overseers, to graze the Church of God which Jesus has acquired with His blood (Acts 20:28-30). The flock belongs to Jesus, he acquired it with his blood. Jesus appoints overseers over God's flock which was entrusted to them. Jesus told Peter three times, "Tend My sheep" (Jn. 21:15-17). Taught by this experience, the apostle Paul warns the elders over the "chosen aliens" (cf. 1 Pt. 1:1-2) to tend to God's flock which was entrusted to them, to oversee it gladly as God wills, with excitement as examples to the flock (cf. 1 Pt. 5:1-3).

The Church as the Fishers of Men. Jesus met the fishermen Peter and Andrew as they were casting their nets into the sea. He called them to come and follow him and he promised he would make them "fishers of men" (Mt. 4:18-20). Here, Jesus uses their proficiency in fishing and uses a picture from fishing to instruct them about this new reality: evangelizing people. Later on, we find a passage where Jesus compares the Kingdom of God with a dragnet, "Again, the kingdom of heaven is like a dragnet cast into the sea, and gathering fish of every kind" (Mt. 13:47).

Summary. Jesus uses the picture of the flock and the shepherd in order to emphasize that his flock is comprised of the few who follow him. He emphasized that he is the Good Shepherd who gives his life for his sheep, and who knows his sheep, and the sheep know him. He is leading his sheep and they follow him because they know his voice. He emphasized that his flock comprises of all those who hear his voice (both Israelites and pagans) and follow him, and that there is only one flock and he is their shepherd. The Holy Spirit appoints overseers over Jesus' flock to tend the flock of God which they were entrusted with. At the center of this picture we see the Church, which comprises of believers who have a proper relationship with Jesus, which is why they are able to hear and recognize his voice, they follow him and they obey his commands.

\section{A Picture from Viticulture}

Jesus uses the picture of the Church as a vineyard (Jn. 15:1-8) in order to emphasize the source of every believer's life, as well as the process which contributes to their fruitfulness. Jesus is the true vine, and God the Father is the vine-dresser. The believers are the branches on the vine. As the vine-dresser, God the Father cuts off from Jesus every branch which does not bear fruit, and he prunes each one that does so that it would bear more fruit. The pruning of believers happens in line with Jesus' words. Believers who are in Jesus and in whom Jesus abides will bring forth fruit. This is why Jesus persists in his demand, "Abide in Me, and I in you" (Jn. 15:4-7). Just as the branch cannot bear fruit on its own if it does not remain on the vine, so believers cannot bear fruit if they do not remain in Jesus. 
When a believer separates himself from Jesus, he withers. Withered branches become dry, and then the vineyard workers gather them and throw them into the fire, and they burn up. Jesus ends his vine-dressing parable by saying, "My Father is glorified by this, that you bear much fruit, and so [a]prove to be My disciples." (Jn. 15.8).

Summary. The picture of the Church as God's vineyard points us to each believer's life source, and to the process which contributes to the fruitfulness of the believer. Jesus is the vine, God the Father is the vine-dresser, and believers are the branches on the vine. As the vine-dresser, God the Father prunes his vineyard - the Church - to make sure that every believer is bearing fruit.

\section{The City: Citizenship in Heaven}

In the early days of the Church, a city (Greek: polis) was a geographic location and the center of power from which the city and the surrounding settlements were governed. Along with secular application, the term "polis" is used in the New Testament as a picture for the Church, first of all due to the special significance that the city of Jerusalem has in the Jewish thought. The picture of the Church is particularly emphasized in Hebrews, where the motif of traveling is used as a picture for Christian life:

"By faith Abraham, when he was called, obeyed by going out to a place which he was to receive for an inheritance; and he went out, not knowing where he was going. By faith he lived as an alien in the land of promise, as in a foreign land, dwelling in tents with Isaac and Jacob, fellow heirs of the same promise; for he was looking for the city which has foundations, whose architect and builder is God (Heb. 11:8-10).

This example emphasizes Abraham's faith in God, obedience to God's Word, uncertainty in the foreign land, and the expectation of the founded City whose builder and creator is God. Many have died as foreigners and newcomers on earth in this same faith, on their way to the heavenly homeland (cf. Heb. 11:1316).

The Scriptures clearly emphasize that the permanent city is not on earth, but that Christians, as travelers, have been traveling to the eschatological, heavenly city, "Therefore Jesus also, that He might sanctify the people through His own blood, suffered outside the gate. So, let us go out to Him outside the camp, bearing His reproach. For here we do not have a lasting city, but we are seeking the city which is to come" (Heb. 13:12-14). While encouraging Christians, the author of Hebrews writes, "But you have come to Mount Zion and to the city of the living God, the heavenly Jerusalem, and to myriads of angels, to the general assembly 
and church of the firstborn who are enrolled in heaven, and to God, the Judge of all, and to the spirits of the righteous made perfect, and to Jesus, the mediator of a new covenant, and to the sprinkled blood, which speaks better than the blood of Abel" (Heb. 12:22-24).

In Revelation, apostle John describes the city of Babylon as the mother of harlots and of the abominations of earth (Rev. 17:1,5,18). He then goes on to describe the Holy City, the New Jerusalem that comes down from heaven from God, prepared as a bride is adorned for her groom, confirmed by the voice from the throne, "Behold, the tabernacle of God is among men, and He will dwell among them, and they shall be His people, and God Himself will be among them, and $\mathrm{He}$ will wipe away every tear from their eyes; and there will no longer be any death; there will no longer be any mourning, or crying, or pain; the first things have passed away" (Rev. 21:3-4).

The Heavenly Citizenship of Christians. Modern Christianity is so heavily involved in earthly political happenings that we can rightly ask ourselves: what and where is the Christian homeland? Through the new birth (Jn. 3:3-8) we were born into the Kingdom of Heaven. What does that mean? Our homeland is in the heavens (Phil. 3:20), and while on earth we are just travelers on God's mission. As ambassadors of the Kingdom of God, we advocate the interests of our homeland (the Kingdom of God) and of our ruler (the King Jesus Christ) wherever we are. We have no right to meddle in the politics and social relations of the country where we temporarily serve our King Jesus, unless the King explicitly tells us to. There are very few examples of this in the Bible, and the most famous one was the example of Moses and the Israelites' exodus from Egypt. We do not find a single example in the New Testament of Christians dabbling in politics or changing social relationships. Jesus did not teach us to change social and political relationships. On the contrary, the apostle Peter reminds us that we are aliens and travelers on this earth, and that we need to behave as such (1 Pt. 2:11-12) and goes on to say, "As obedient children, do not be conformed to the former lusts which were yours in your ignorance, but like the Holy One who called you, be holy yourselves also in all your behavior; because it is written, 'You shall be holy, for I am holy.' If you address as Father the One who impartially judges according to each one's work, conduct yourselves in fear during the time of your stay on earth" (1 Pt. 1:14-17). ${ }^{18}$

Summary. The picture of the Church as the heavenly City, the new Jerusalem, points to the heavenly citizenship of Christians. The homeland of Christians is

18 We can think about Christian patriotism in that context. If Christians are only in transit in this world, should they be in politics and should they be express their patriotism toward their national state? The Christians' homeland is in the heavens, and not on earth. 
in the heavens, and while on this earth, Christians are just travelers on God's mission. The Church is a community of hope traveling through, that includes faith in God, obedience to God's Word, uncertainty in the foreign land, and expecting the founded City whose builder and creator is God, as well as the hardships and constant separation from the prevailing values of the sinful world.

\section{Models of the Church for the 21st Century}

While considering the three groups of Church models, we have noticed that the models which are formed by life and man-made models are, for the most part and some of them even completely, opposed to the Biblical model of the Church, and can only serve as negative examples in applying the Biblical model of the Church. Simply put, instead of the Triune God (Father, Son Jesus Christ, and the Holy Spirit) and his Word, during history and even today the models of the Church have often reflected the political and religious systems (Roman Catholic and Eastern Orthodox Christianity), the culture of enlightenment and science (liberal Christianity), pragmatic philosophy (the faith movement, the healing movement, the charismatic movement), humanism, spiritualism, and pantheism (the ecumenical movement and the inter-religious dialogue movement), philosophical and cultural trends (progressive Christianity).

The 21st century Church has been called to establish and apply the Biblical Church model. In establishing the model, we need to focus on God and his purposes and plans for a specific time, place, and culture. Our communication with God must be fully open, and the Church needs to be prepared to follow God's plans and the Holy Spirit's guidance. Of course, we also need to bear in mind various theological developments throughout history, different spiritual movements in the past and today, trends in Church history, social movements, and Church heritage in order to have an insight into both the positive and negative spiritual fruits as pertaining to God's immutable Word.

After over thirty years of working in pastoral and teaching ministry I have concluded time and time again that imitating and following "successful," growing, and large churches is the most challenging wrong way to establish a Church model. Why? Following or imitating cannot and will not be successful, because each Church lives and works in a particular spiritual, social, and political climate, and a specific culture. Each Church possesses different spiritual, material, and social resources which God had prepared and equipped for the culture and area where they gather. And yet, in establishing the Church model we need to learn both from the failed Church models as well as from the successful ones. Each Church model has its own strong and weak points and limitations. 
Since the Church of the 21 st century is continually under great social pressure to be socially relevant and fruitful, it is also in constant danger of failing to trust in God and his resources as it develops its Church models but on socially acceptable resources such as politics, philosophy, cultural trends, etc. Dražen Glavašs research, Christian on Sunday, atheist on Monday: How Do We Bridge the Gap Between Faith And Work In Croatian Culture? shows the negative consequences of the adopted ${ }^{19}$ Church models, be they Catholic, Orthodox, Protestant, or Evangelical. The Church is weakened because the adopted models are largely secularized, and thus deprived of God's guidance, wisdom, and power. Glavaš confirmed this in his research, "We've come to realize that most Croats profess to be Christian, but at the same time we find a high level of corruption in the Croatian market. Affirmation of faith (values, virtues, etiquette) in the workplace is completely absent, and the gap between God on Sunday and Mammon on Monday is getting wider and wider" (Glavaš 2017, 37).

Due to the complexity of the Church, no single model can offer the full spiritual reality of the Church. Each contemporary model is only successful for a time, to a generation of believers in an area which God has prepared for that model. Each generation needs to be reached for Christ by methods which will make the immutable Word of God fruitful as the Good News.

In its attempts to make the world a better place, modernism emphasized information about God, human endeavors and manipulations, reason, rationality, human wisdom, and worldly ideas. This drove the Church into a crisis due to "God's absence." Instead of information about Jesus Christ, 21st century Christians need to bring Jesus Christ into the lives of people and into fellowship with Christ. In other words, instead of bringing knowledge about God, Christians need to allow non-Christians to experience fellowship with God. The only effective Church model is the one that is compatible with the post-modern person, which will help that post-modern person come to know Jesus and bring them into the Kingdom of God and into fellowship with others who are saved (cf. Scanlen 2005, 97). Post-modernists will gladly join the fellowship of a Church which is experientially different, is lead by the Holy Spirit, empowered by the Spirit, focused on God the Father and Jesus Christ, and in service to God and the needy. The Church needs to rely on the guidance and power of the Holy Spirit, and to avoid any kind of control or manipulation, which are like cancer that destroys the

19 I'm emphasizing the difference between proclaimed and adopted Church models. A proclaimed Church model is a lengthy wish list which is rooted in the official teaching or doctrine of a certain denomination, including the Roman Catholic and Eastern Orthodox Churches. An adopted Church model is one where the believers have adopted its theory and practice and they live by it in all aspects of human life. 
fellowship of saints.

Since Jesus Christ is building his Church and is using people for that, the Church needs to make a turn from a rational and emotional religion towards God's dwelling in the fellowship of the Church. The Church needs to observe what is it that God is doing in its midst and to live and act accordingly (cf. Jn. 5:19.30). The apostle Paul stressed this beautifully, "For we are His workmanship, created in Christ Jesus for good works, which God prepared beforehand so that we would walk in them" (Eph. 2:10).

Each Church model contains both divine and human elements. God's elements are immutable in any Church model. What can and needs to be changed are the human elements. Which elements are God's and which are human? In other words, what is it that is immutable about the Church model, and what can and needs to be changed?

Based on our review of the Biblical Church models, we conclude that Biblical models of the 21 st century Church need to incorporate all Biblical pictures of the Church as various perspectives or views on the Church model. A Church model needs to reflect:

- God the Father - the Creator of all that exists and the owner of the Church;

- Jesus Christ - Savior, Lord, builder, and the Head of the Church;

- The Holy Spirit - the guide, the one who empowers, defender, and giver of the Church;

- The Word of God - the Bible as the creative Word and the absolute standard of truth;

- God's way of life according to His Word in the power of the Holy Spirit;

- Doing God's will in everyday circumstances.

The 21 st century Church is in grave danger of accepting relativism and watering down of God's element in the Church model. Social and cultural movements such as post-modernism, relativism, humanism, ecumenism, and inter-religious dialogue have redefined fundamental Biblical terms such as God, Jesus Christ, Holy Spirit, God's Word, and God's will. That is why the $21^{\text {st }}$ century Church model needs to firmly discard these redefined Biblical terms and adopt the original Biblical terms. God is immutable, which is why all the permanent and immutable elements in the Church come from God. That is primarily the creative Word of God, which includes God's immutable revelation and will.

God's Word remains forever the same and it never changes. Jesus confirmed this, "Heaven and earth will pass away, but My words will not pass away" (Mt. 24:35). The 21st century Church model must incorporate preaching of the immutable Gospel as the absolute Word of God. Christians needs to live in a holy way according to the Word of God so they could make a difference in the world around 
them. The emphasis is on life which brings changes into society as its fruit. The goals of the Church are not and must not be changes in society, politics, or culture, but helping individuals come to know Jesus Christ who changes them after His own image through the Holy Spirit. These changed, Word-filled, and Spirit-lead and empowered individuals live a life which is used by the Holy Spirit for Christlike changes in the family and society. The apostle Peter emphasizes, "Beloved, I urge you as aliens and strangers to abstain from fleshly lusts which wage war against the soul. Keep your behavior excellent among the Gentiles, so that in the thing in which they slander you as evildoers, they may because of your good deeds, as they observe them, glorify God in the day of visitation (1 Pt. 2:11-12).

The human, mutable, elements in the 21st century Church model include church structures, church leadership, the kind, ways, and places of worship, the place and ways of serving in the world. ${ }^{20}$ These human, changeable elements are in fact changeable due to obeying God's immutable will in a changeable culture. The human elements need to be aligned with the Word of God and the guidance of the Holy Spirit. By doing God's will, the Church is unstoppable in changing every culture. That's why the 21 st Church was called to create a good climate for:

- Each individual's living relationship with God and of the fellowship in general (the Body of Christ), both local, as well as the city-level, regional, and global.

- Obeying God's will through:

- The works which God has prepared for each believer to walk in them (Eph. 2:10),

- The works which God commanded Christians to do (Jn. 14:21; 15:10),

- The works of love whenever a need arises (Titus 3:8,14).

- Living which God has empowered for in the power of the Holy Spirit.

- Good relationship between believers in families and in the Church.

Relationships and fellowship are common to all Biblical pictures of the Church. God, as the King, Head, Father, and Builder, has a relationship and fellowship with his people as a community. Church has a relationship with Jesus as his bride, his flock, family, body, and a living spiritual house. Believers are mutually connected as members of the same body, building blocks in the same building,

20 The Church is unable to operate without institutional elements. From the very beginning, the Church had institutional elements, such as recognized ministries and ministers, accepted creeds and forms of public worship. The Church needs structures, but they aren't necessarily in the service of obeying God's will. Church leadership needs to lead believers in obeying God's will in God's authority and power, and not in the authority of Church as a social community. 
sheep in the same flock, children in the same family. Establishing relationships between believers in the modern Church needs to be changed from the standard of friendship, common interests, games, and fun into the standard of the Body of Christ and the mutual connection of members by function, where each member plays its role in the Body. In the Body of Christ, we have the most intimate fellowship with the members we are directly connected to, or which are directly connected to us, and through which we run all our supply lines with the Head, Jesus Christ.

The Church is not a group of isolated individuals but a community of people whom God had called to live and serve together according to God's will and the power of the Holy Spirit. It is a specific community of believers who are owned by God, which lives among non-believers according to God's commands and standards.

The New Testament picture of the Church as God's people indicates a community of believers who are owned by God, who need to be separated from the world, whom God is going to dwell in, who will happily testify to the fact that God is their personal God, and who will live and serve together according to God's will and in the power of the Holy Spirit.

Each picture or Church model that the Bible uses reminds us and points to the dynamic reality of the Church which is built by Jesus Christ. The New Testament brings us a variety of different pictures of the Church because of human limitations in understanding God, his will, love, righteousness, truth, and his work in the Church and in the world. Thus, each picture of the Church communicates specific realities which the Church can and should live by. The fact that the Church is like a family leads us to love one another even more and to have spontaneous relationships with each other. The knowledge that the Church is the bride of Christ encourages us to prepare ourselves for the encounter and eternal life with the groom, and to live a pure and consecrated life. God's people are God's building, "a house not made with hands" (2 Cor. 5:1), a building built by God. The Old Testament temple became a people in which God now abides through his Spirit. Jesus Christ is the foundation, the cornerstone of this building (1 Cor. 3:11,16, Eph. 2:20-22), and Christians are living "stones" which are built into this building (1 Pt. 2:4-8). The picture of the Church as the Body of Christ points us primarily toward the Head - Jesus Christ - and the Holy Spirit who empowers us and gives us all we need to be able to grow together, worship God together, and serve him in the world. Christian fellowship is not something they need to accomplish in their own strength and skill; instead, it is a blessing from God to which they need to surrender and enjoy it. 


\section{Conclusion}

History shows us that the Church is constantly changing. These changes were happening in a dynamic relationship of obedience and disobedience to God and obeying and neglecting his Word. During twenty centuries, the Church has impacted different models of living. Church models were developed, established, and altered during constant and dynamic spiritual struggle in specific life situations in fellowship with God, and in attempts to preserve and obey God's will on one hand, and in distancing from God and conforming to this world on the other (cf. Rom. 12:1-2). In this review we have considered three model categories: Church models formed by everyday life, Church models made by man during history, and Church models founded in the Word of God. Church models which are formed by everyday life today and the Church models made by man throughout history can serve as negative examples of what emerges as we try to adapt the Church to the world. These models need to be changed as the Church lives according to Biblical models, in fellowship and obedience to God.

The Bible reveals the specific reality and nature of the Church by using numerous different pictures from everyday life. In communicating with man, God uses pictures which are familiar to humans, easy to understand, and experientialy affirmed. These pictures come from the ownership system, from the way human body works, from marriage and family life, from architecture, agriculture, cattle breeding, fishery, and vine-dressing. These pictures reflect life and point to life. Each of the pictures communicates one or more God's truths in a way that is very close and familiar to the listeners and readers.

From being sick, God's Church is changing into a healthy one by choosing and applying the Biblical model of living. By applying man-made models, the Church becomes and remains an organized and institutionalized community of people in which God is seldom present, despite good intentions and creeds. The Biblical Church model contains God's (immutable) and human (mutable) elements. God is immutable, which is why all that is permanent and immutable in Church comes from God. The Biblical model of the Church reflects God the Father, the creator of all that exists and owner of the Church; Jesus Christ, Saviour, Lord, builder, and the Head of the Church; Holy Spirit, the guide, one who empowers, defends, and gifts the Church; the Word of God, the Bible as the creative Word and the absolute standard of truth; God's way of Church life according to his Word in the power of the Holy Spirit; and doing God's will in everyday situations.

The human, mutable, elements in the 21st Church model include church structures, church leadership, the type, time, ways, and place of meetings, time, type, and ways of worship, place and ways of serving in the world. The human elements need to be aligned with God's Word and the guidance of the Holy Spirit 
so that the Church could fruitfully obey God's will. The 21st century Church is called to create a climate for: a living relationship with God for every individual and the community in general (the Body of Christ); obeying God's will by doing works which God had prepared for every believer to abide in them (Eph. 2:10), works which God has commanded Christians to do (Jn. 14;21; 15:10), works of love whenever the need arises (Titus 3:8,14), and life which God has enabled us to have in the power of the Holy Spirit.

\section{Literature}

Addison, Steve. 2011. Movements That Change the World. Downers Growe. IVP Books.

Barna, George, Viola, Frank. 2002. Pagan Christianity?: Exploring the Roots of Our Church Practices (Revised an updated). USA: Tyndale Momentum.

Bird, Michael F. 2013. Evangelical Theology: A Biblical and Systematic Introduction. Grand Rapids. Zondervan.

Časni, Danijel. 2016. The Church In A Democratic Society And Democracy In Reformation-Heritage Churches With An Emphasis On The Baptist Church In Croatia. Kairos: Evangelical Theological Journal 10/1. https://hrcak. srce.hr/160011

Davie, Martin, Tim Grass, Stephen R. Holmes, John McDowell, T. A. Noble (urr.). 2017. New Dictionary of Theology Historical and Systematic. London - Downers Grove. InterVarsity Press.

Dulles, Avery. 1987. Models of the Church (Expanded edition). New York, Doubleday.

Ferguson, Everett. 1996. The Church of Christ: A Biblical Ecclesiology for Today. Grand Rapids. Eerdmans.

Fitzmyer, Joseph A. 2008. First Corinthians. New Heaven and London: Yale University Press.

Getz, Gene A. 1995. Church In Focus: Biblical, Historical, And Cultural Understanding Of The Church. Zagreb. Susret.

Glavaš, Dražen. 2017a. Christian On Sunday, Atheist On Monday: How To Bridge The Gap Between Faith And Work In Croatian Culture - part I. Kairos: Evangelical Theological Journal 1/2017. pgs. 29-67.

Glavaš, Dražen. 2017b. Christian On Sunday, Atheist On Monday: How To Bridge The Gap Between Faith And Work In Croatian Cultur- part II. Kairos: Evangelical Theological Journal 2/2017. pgs. 169-198. 
Goheen, Michael W. 2011. A Light to the Nations: The Missional Church and the Biblical Story. Grand Rapids. Baker Academic.

Grudem, Wayne. 1994. Systematic Theology: An Introduction to Biblical Doctrine. Leicester. Inter-Varsity Press.

Harrison, John, James D. Dvorak (ed.). 2012. The New Testament Church: The Challenge of Developing Ecclesiologies. McMaster Biblical Studies Series. Eugene. Pickwick.

Hellerman, Joseph H. 2009. When the Church was a Family: Recapturing Jesus' Vision for Authentic Christian Community. Nashville, Tennessee: B\&H Academic.

Horton, Michael. 2011. The Christian Faith. Grand Rapids. Zondervan.

Humphreys, Fisher. 2016. Razmišljanje o Bogu: Uvod u kršćansku teologiju. Zagreb. Biblijski institut.

Jambrek, Stanko. 2003. Crkve reformacijske baštine u Hrvatskoj. Zagreb: Bogoslovni institut.

Kärkkäinen, Veli-Matti. 2002. An Introduction to Ecclesiology: Ecumenical, Historical and Global Perspectives. InterVarsity.

Marshall, Tom. 2003. Understanding Leadership. Ada, MI. Baker Books.

Marti, Gerardo i Ganiel, Gladys. 2014. The Deconstructed Church: Understanding Emerging Christianity. New York. Oxford University Press

Martin, Ralph P. 1979. The Family and the Fellowship: New Testament Images of the Church. Eugene. Wipf a Stock Publishers.

Minear, Paul S. 1960. Images of the Church in the New Testament. Philadelphia. Westminster.

Moore, John, Ken Neff. 1985. A New Testament Blueprint for the Church. Chicago. Moody Press.

Niemandt, Cornelius J. P. 2012. Trends in missional ecclesiology. HTS Teologiese Studies / Theological Studies, 68(1), 1-9. https://doi.org/10.4102/hts. v68i1.1198

Peterlin, Davorin. 2010. Stomach, arms, legs, feet, eyes, ears, mouth, upper and lower teeth, molars, eyebrows, and head: Unity of Christians and the ancient topos of the body and limbs. Kairos: Evangelical Theological Journal Vol. 4 (No. 1): 75-92.

Scanlen, Andries Stephanus. 2005. A Critical Evaluation of Avery Dulles' Different Models of the Church Applied to a Contemporary World. Master Thesis. University of Johannesburg.

Small, Joseph D. 2012. Presbyterianism's Democratic Captivity. First Things 221 (March). 
Small, Joseph D. 2018. Flawed Church, Faithful God: A Reformed Ecclesiology for the Real World. Grand Rapids. Eerdmans.

Stagg, Frank. 1987. New Testament Theology. Novi Sad. Dobra vest.

Van Gelder, Craig. 2001. The Essence of the Church: A Community Created by the Spirit. Grand Rapids. Baker Books. Kindle.

Van Gelder, Craig. 2005. Rethinking denominations and denominationalism in light of a missional ecclesiology. Word \& World, 25(1), 23-33.

Viola, Frank. 2005. The Untold Story of the New Testament Church: An Extraordinary Guide to Understanding the New Testament. Shippensburg, Destiny Image Publishers.

Viola, Frank. 2008. Reimagining Church: Pursuing the Dream of Organic Christianity. Colorado Springs. David C. Cook.

Warren, Rick. 1995. The Purpose Driven Church. Grand Rapids. Zondervan.

Wells, David F. 2008. The Courage To Be Protestant. Nottingham. Inter-Varsity Press.

Williams, J. Rodman. 1992. Renewal Theology: The Church, the Kingdom, and Last Things. Grand Rapids. Zondervan Publishing House.

Translated from Croatian by Davor Edelinski

Stanko Jambrek

\title{
Modeli Crkve za 21. stoljeće
}

\author{
Sažetak
}

Za plodonosno razumijevanje prirode Crkve Biblija koristi niz slika i metafora koje zajednički tvore modele Crkve po kojima vjernici žive i djeluju. Modele Crkve razmotrili smo u tri kategorije: prvu čine modeli Crkve koje danas kreira svakodnevni život, drugu čine modeli Crkve koje su kroz povijest osmislili ljudi i, treću, modeli Crkve utemeljeni u Riječi Božjoj.

Modeli Crkve koje danas kreira svakodnevni život i modeli Crkve koje su kroz povijest osmislili ljudi služe nam kao negativni primjeri modela koje treba mijenjati i izbjegavati, posebice modele Crkve kao institucije i kao denominacije. Kršćanstvo 21. stoljeća treba usvojiti i primijeniti biblijske slike Crkve koje zajednički tvore biblijski model Crkve. 
Biblija prikazuje specifičnu stvarnost i narav Crkve brojnim i različitim slikama i metaforama iz svakodnevnog života. Među njima su slike iz sustava vlasništva; slika funkcioniranja ljudskoga tijela; slike predbračnog, bračnog i obiteljskog života; slike iz područja graditeljstva, poljodjelstva, stočarstva, ribarstva te građanstva i domoljublja. Svaka od upotrijebljenih slika i metafora komunicira jednu ili više Božjih istina na način koji je iskustveno vrlo blizak i poznat slušateljima i čitateljima. Te su slike odraz života i upućuju na život.

Crkva 21. stoljeća pozvana je uspostaviti i primjenjivati biblijski model Crkve. Pri uspostavi modela trebamo se usredotočiti na Boga i njegove svrhe i planove za konkretno vrijeme, prostor i kulturu. Komunikacija s Bogom treba biti potpuno otvorena, a Crkva spremna slijediti Božje planove i vodstvo Svetoga Duha.

Biblijski model Crkve sadrži Božje (nepromjenjive) i ljudske (promjenjive) elemente. Bog je nepromjenjiv, stoga je trajno i nepromjenjivo u Crkvi sve ono što dolazi od Boga, a mijenjati se može i mora sve ono što je došlo od ljudi. Ljudski elementi trebaju biti u skladu s Riječi Božjom i vodstvom Svetoga Duha kako bi Crkva plodonosno vršila Božju volju. 
